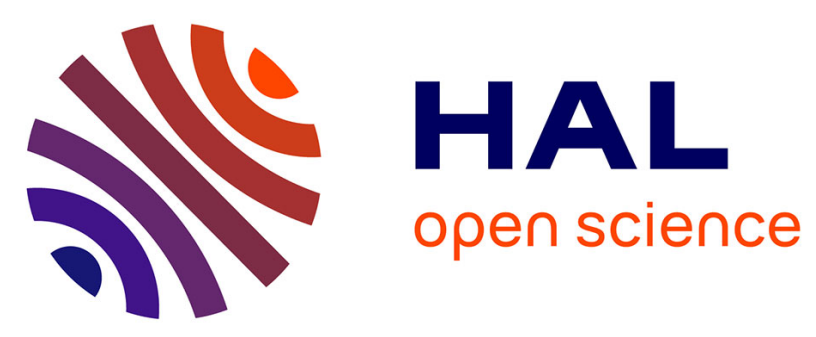

\title{
The colloidal stabilization of young red wine by Acacia senegal gum: The involvement of the protein backbone from the protein-rich arabinogalactan-proteins
}

Michael Nigen, Rafael Apolinar Valiente, Nerea Iturmendi, Pascale Williams, Thierry Doco, Virginie Moine, Arnaud Massot, Isabelle Jaouen, Christian Sanchez

\section{To cite this version:}

Michael Nigen, Rafael Apolinar Valiente, Nerea Iturmendi, Pascale Williams, Thierry Doco, et al.. The colloidal stabilization of young red wine by Acacia senegal gum: The involvement of the protein backbone from the protein-rich arabinogalactan-proteins. Food Hydrocolloids, 2019, 97, 10.1016/j.foodhyd.2019.105176 . hal-02164154

\section{HAL Id: hal-02164154 \\ https://hal.science/hal-02164154}

Submitted on 26 May 2020

HAL is a multi-disciplinary open access archive for the deposit and dissemination of scientific research documents, whether they are published or not. The documents may come from teaching and research institutions in France or abroad, or from public or private research centers.
L'archive ouverte pluridisciplinaire HAL, est destinée au dépôt et à la diffusion de documents scientifiques de niveau recherche, publiés ou non, émanant des établissements d'enseignement et de recherche français ou étrangers, des laboratoires publics ou privés. 


\section{Accepted Manuscript}

The colloidal stabilization of young red wine by Acacia senegal gum: The involvement of the protein backbone from the protein-rich arabinogalactan-proteins

Michaël Nigen, Rafael Apolinar Valiente, Nerea Iturmendi, Pascale Williams, Thierry

Doco, Virginie Moine, Arnaud Massot, Isabelle Jaouen, Christian Sanchez

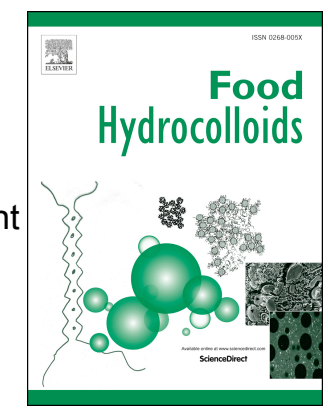

PII:

S0268-005X(19)30393-5

DOI:

https://doi.org/10.1016/j.foodhyd.2019.105176

Article Number: 105176

Reference: FOOHYD 105176

To appear in: Food Hydrocolloids

Received Date: 18 February 2019

Revised Date: 21 May 2019

Accepted Date: 18 June 2019

Please cite this article as: Nigen, Michaë., Valiente, R.A., Iturmendi, N., Williams, P., Doco, T., Moine, V., Massot, A., Jaouen, I., Sanchez, C., The colloidal stabilization of young red wine by Acacia senegal gum: The involvement of the protein backbone from the protein-rich arabinogalactan-proteins, Food Hydrocolloids (2019), doi: https://doi.org/10.1016/j.foodhyd.2019.105176.

This is a PDF file of an unedited manuscript that has been accepted for publication. As a service to our customers we are providing this early version of the manuscript. The manuscript will undergo copyediting, typesetting, and review of the resulting proof before it is published in its final form. Please note that during the production process errors may be discovered which could affect the content, and all legal disclaimers that apply to the journal pertain. 

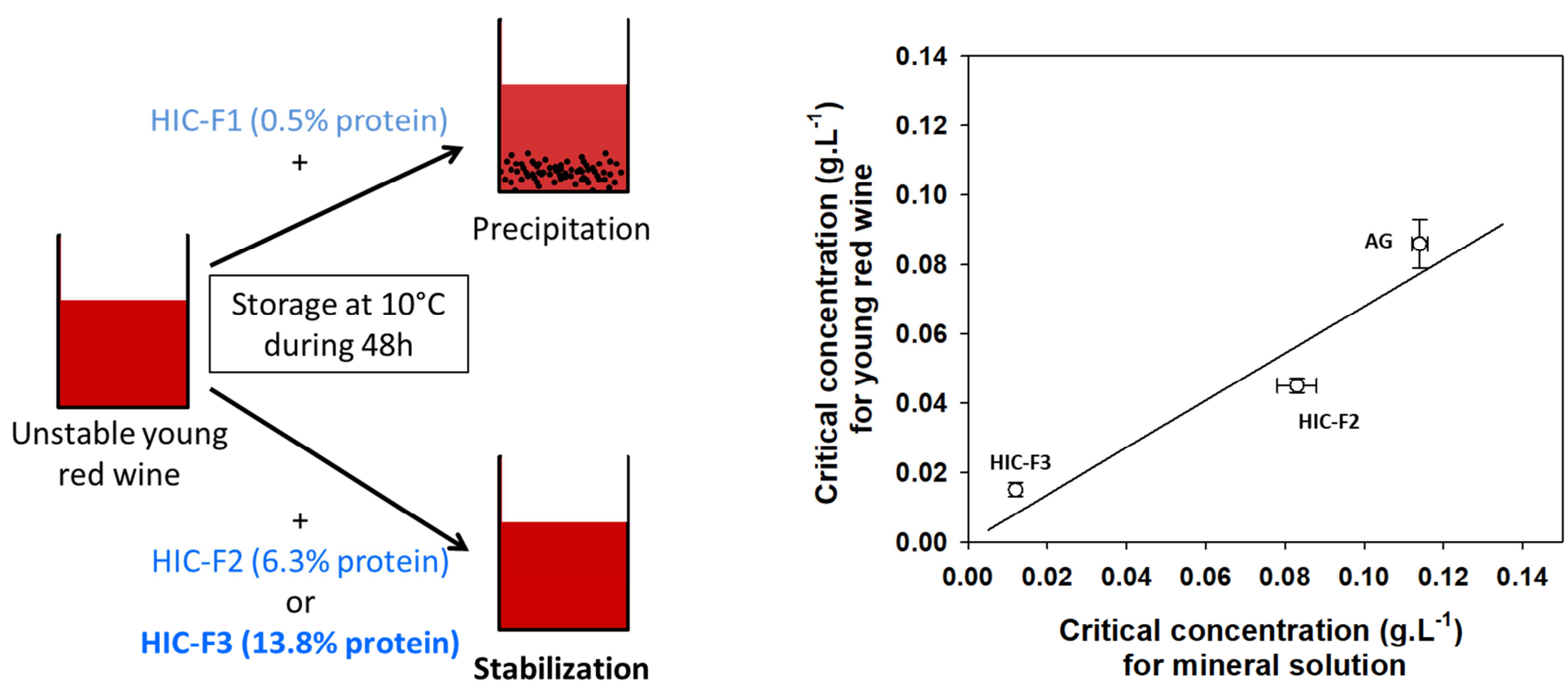

Graphical Abstract. 
1 The colloidal stabilization of young red wine by Acacia

2 senegal gum: The involvement of the protein backbone from the protein-rich arabinogalactan-proteins

4

5

6 Michaël Nigen ${ }^{\mathrm{a} *}$, Rafael Apolinar Valiente ${ }^{\mathrm{a}}$, Nerea Iturmendi ${ }^{\mathrm{c}}$, Pascale Williams ${ }^{\mathrm{b}}$, Thierry Doco $^{\mathrm{b}}$, Virginie Moine ${ }^{\mathrm{c}}$, Arnaud Massot $^{\mathrm{c}}$, Isabelle Jaouen ${ }^{\mathrm{d}}$ and Christian Sanchez ${ }^{\mathrm{a}}$

${ }^{a}$ UMR1208 Ingénierie des Agropolymères et Technologies Emergentes, INRA-Montpellier 10 SupAgro-CIRAD-Université Montpellier, 2 Place Pierre Viala F-34060 Montpellier, France 11

$12{ }^{\mathrm{b}}$ UMR 1083 Science Pour l'Enologie, INRA-Montpellier SupAgro-Université Montpellier, 2 13 Place Pierre Viala F-34060 Montpellier, France

14

${ }^{\mathrm{d}}$ ALLAND \& ROBERT, 9 rue Saintonge, 75003 Paris, France 


\section{Abstract}

The arabinogalactan-proteins (AGPs) type biopelymers from Acacia senegal gum are used as protective colloid in young red wines to prevent the precipitation of the coloring matter. Usually, Acacia senegal gum is chosen based on its efficiency to stabilize iron hexacyanoferrate salts in hydro-alcoholic solution. In this study, the protective activity of Acacia senegal gum and its three macromolecular fractions (HIC-F1, HIC-F2 and HIC-F3), separated according to their hydrophobicity, towards the precipitation of iron hexacyanoferrate salts and polyphenols in hydro-alcoholic solutions are reported. The-AGPs prevent the colloidal instability of both iron hexacyanoferrate salts and polyphenols in "model" hydro-alcoholic solutions and young red wine with a good correlation between results obtained on both systems. This result then-strengthens the use of iron hexacyanoferrate salts (hydro-alcoholic - mineral test) for the evaluation of the protective activity of A. senegal gum in young red wine. The precipitation of iron hexacyanoferrate salts is avoided by the electrostatic binding of $\mathrm{Ca}^{2+}$, the driver of the instability, with the-negatively charged carried by amino-acids from the protein backbone or both by amino acids and uronic acid monosaccharides localized close to the protein backbone of AGPs. The protective activity closely depends on the protein content of AGPs in both iron hexacyanoferrate salts and polyphenols hydro-alcoholic solutions: the more they are rich in proteins, the more their colloidal stabilizing efficiency is (HIC-F3>HIC-F2>HIC-F1). The differences observed in the protective activity between AGPs from the three HIC fractions are relied not only to their protein content but also to their related rate of glycosylation that modulates the protein accessibility to its environment, then their physicochemical properties as their hydrophobic behavior. 
Keywords: Acacia gum, Arabinogalactan proteins, colloidal stability, young red wine,

50 coloring matter

\section{Introduction}

Red wine is a mixture of water, alcohols, organic acid and of complex molecules at the origin of its organoleptic properties and in constant evolution during ageing. The color as well as the clarity of red wines are ones of the qualities required by the consumers. Red wines must present a colloidal stability not only at the time of bottling but also during ageing and storage until its consumption (Ribéreau-Gayon, Glories, Maujean \& Dubourbieu, 2006). The phenolic compounds, responsible of the organoleptic perceptions, are also unstable molecules able to aggregate and precipitate both in young and aged red wines (Ribéreau-Gayon et al., 2006; Alcade-Eon, Garcia-Estévez, Puente, Rivas-Gonzalo \& Escribano-Bailon, 2014). Among others, the phenolic compounds can react with ferric iron to form soluble complexes that may then flocculate and precipitate during ageing (Ribéreau-Gayon et al., 2006). The colloidal stability in young red wines may be ensured by several techniques as a cold treatment, fining or addition of protective colloids such as carboxymethyl cellulose, metatartaric acid, mannoproteins and Acacia gum (Waters, Pellerin \& Brillouet, 1994; Waters, Pellerin \& Brillouet, 1994a; Dupin, Stockdale, Williams, Jones, Markides \& Waters, 2000; Escot, Feuillat, Dulau \& Charpentier, 2001; Riou, Vernhet, Doco \& Moutounet, 2002; RiberauBlouin \& Crachereau, 2010; Teissedre, 2012; Gordillo, Cejudo-Bastante, Rodríguez-Pulido,

70 Jara-Palacios, Ramírez-Pérez, González-Miret \& Heredia, 2014). The cold and fining treatments cause the precipitation of existing particles responsible of the turbidity as well as those potentially formed during ageing. Therefore, both treatments have a clarifying and a stabilizing action (Riberau-Gayon et al., 2006). In young red wine, Acacia gum is used as a 
74 protective colloid in order to prevent or limit the aggregation and precipitation of unstable

75 colloids as the coloring matter (Ribereau-Gayon et al., 2006; Teissedre, 2012). In particular,

76 Acacia gum macromolecules bind to polyphenols by the involvement of both hydrogen

77 bonding and hydrophobic interactions that prevents their interaction and aggregation with

78 proteins (de Freitas, Carvalho \& Mateus, 2003; Mateus, Carvalho, Luis \& de Freitas, 2004;

79 Soares, Gonçalves, Fernandes, Mateus \& de Freitas, 2009; Soares, Mateus \& de Freitas, 2012;

80 Chung, Rojanasasithara, Mutilangi \& McClements, 2016). Hence, Acacia gum is mainly used

81 in young red wine for its colloidal stabilizing properties. It stabilizes young red wine but does

82 not clarify it.

Acacia gum is a natural exudate obtained from the trunk and branches of Acacia senegal and Acacia seyal trees (Williams \& Phillips, 2000). Acacia gum macromolecules are highly glycosylated hydroxyproline-rich arabinogalactan-proteins (AGPs) belonging to the glycoprotein superfamily (Akiyama, Eda \& Kato, 1984). AGPs from Acacia gum are mainly composed by sugars (D-galactose, L-arabinose, L-rhamnose, D-glucuronic acid, and 4-Omethyl-D-glucuronic acid) with a small fraction of proteins and minerals (Idris, Williams \& Phillips, 1998; Lopez-Torrez, Nigen, Williams, Doco \& Sanchez, 2015). The sugars are organized into hyperbranched polysaccharide blocks covalently linked to the polypeptide backbone in serine- and hydroxyproline-rich domains (Lopez-Torrez et al., 2015). The highly branched polysaccharide structure is formed by main chains of 1,3 -linked $\beta$-Dgalactopyranose substituted by side chains in O-6 position. Units of $\alpha$-L-arabinofuranosyl and $\alpha$-L-rhamnopyranosyl are distributed in the main and side chains while $\beta$-Dglucuronopyranosyl and 4-O-methyl- $\beta$-D-glucuronopyranosyl are mostly end-units (Anderson, Hirst \& Stoddart, 1966; Anderson \& Stobbart, 1966; Lopez-Torrez et al., 2015).

A. senegal gum can be defined as a continuum of AGPs differing by their sugar, amino acid and mineral content and composition, sugar to amino acid ratio, polarity, number of charges, 
molar mass, size and shape (Randall, Phillips \& Williams, 1989; Islam, Phillips, Sljivo, Snowden \& Williams, 1997; Renard, Lavenant-Gourgeon, Ralet \& Sanchez, 2006; Mejia Tamayo, Nigen, Apolinar-Valiente, Doco, Williams, Renard \& Sanchez, 2018). These AGPs can be separated according to their polarity using hydrophobic interaction chromatography (HIC) with the recovery of three fractions (Randall et al., 1989; Renard et al., 2006). These three fractions were historically named arabinogalactan (AG), arabinogalactan-protein (AGP) and glycoprotein (GP) according to their protein content and elution order. However, allt the ability of these three fractions to bind the $\beta$-glucosyl Yariv's reagent suggests that they all belong to the AGP family because of their reactivity to the Yariv's reactant (Osman et al. 1993). Hence, to avoid any confusion, we named them HIC-F1 (arabinogalactan, AG), HICF2 (arabinogalactan-protein, AGP) and HIC-F3 (glycoprotein, GP) in their order of elution, reflecting also an increasing hydrophobic index. HIC-F1 is the most abundant fraction (85$92 \%$ of the whole gum) as compared to HIC-F2 (6-16\% of the whole gum) and HIC-F3 (1-3\% of the whole gum). The sugar composition was similar between the three fractions, with however a larger content of arabinose in HIC-F2 and HIC-F3 and a larger content of charged sugars in HIC-F1. HIC-F3 was the richest fraction in proteins with values around $25-40 \%$, while the amount of proteins was around $8-10 \%$ and $0.5-1 \%$ for HIC-F2 and HIC-F1, respectively. These three HIC fractions differed also by their mean molar mass $\left(\mathrm{M}_{\mathrm{w}}\right)$ and high $\mathrm{M}_{\mathrm{w}}$ AGPs content (AGPs with $\mathrm{M}_{\mathrm{w}}$ upper than $10^{6} \mathrm{~g} \cdot \mathrm{mol}^{-1}$ ). HIC-F1 was mainly composed of low $\mathrm{M}_{\mathrm{w}}$ AGPs, while HIC-F2 and HIC-F3 were richest in high $\mathrm{M}_{\mathrm{w}}$ AGPs.

In young red wines, it is advised to use Acacia senegal gum at a maximal concentration of 300 mg/L (Code International des Pratiques Enologiques, Fiche Code OIV (12/72) - Edition 01/2015 II.3.3-7) even if no legal limit exists in the EC 606-2009. Before its addition in young red wines, the efficiency of A. senegal gum towards wine colloidal instability is evaluated according to an "efficacy test" of the International Oenological Codex (International 
124 Oenological Codex: COEI-1-GOMARA, 2000). This "efficacy test" consists in determining

125 the quantity of A. senegal gum required to prevent the flocculation of a colloidal iron

126 hexacyanoferrate solution in hydro-alcoholic medium by calcium salt. Hence, the A. senegal

127 gum efficiency towards wine colloidal instability is usually evaluated using a hydro-alcoholic

128 - mineral solution which seems in appearance far enough from wine matrices on their

129 biochemical and physicochemical properties. The colloidal stabilization of two so different

130 matrices by A. senegal gum raises some questions on the colloidal stability mechanism and

131 especially on the AGPs at the origin of this colloidal stabilization.

132 The aim of this study was to investigate the colloidal stabilizing properties of AGPs from A.

133 senegal gum in three hydro-alcoholic solutions: a hydro-alcoholic - mineral solution, "wine-

134 like" solution and young red wine. The AGPs responsible of the colloidal stability in the three

135 hydro-alcoholic solutions were identified. Furthermore, the colloidal stabilization mechanism

136 involving AGPs from A. senegal gum in hydro-alcoholic - mineral solution was

137 characterized.

\section{Materials and Methods}

\subsection{Materials}

141 Instant spray dried Acacia senegal gum was provided by ALLAND \& ROBERT Company -

142 Natural and organic gums (Port Mort, France). A. senegal gum was fractionated by

143 hydrophobic interaction chromatography (HIC) according to Renard et al. (Renard et al.,

144 2006). Three HIC fractions were isolated that wereand named HIC-F1, HIC-F2 and HIC-F3

145 according to their elution order, and then their hydrophobic behaviour. The biochemical

146 composition and structural properties (mean molar mass) of A. senegal gum and HIC

147 fractions were described by Mejia-Tamayo (Mejia-Tamayo et al., 2018) and presented in 148 supplementary data (Table S1). 
149 The pronase was from streptomyces griseus (lot 10165921001, Roche). The grape marc

150 powder rich in polyphenols (64\%) was provided by Grap'Sud Company (Cruviers-Lascours,

151 France). The unstable young red wine (Cabernet sauvignon/Merlot, 2015) was provided by

152 BioLaffort Company (Bordeaux, France). All other reagents were of analytical grade from

153 Sigma-Aldrich (USA).

154

155

156

157

158

159

160

161

162

163

164

165

166

167

168

169

170 and air bubbles.

171

172

\subsection{Hydrolysis of Acacia senegal gum and HIC-F1 fraction by pronase}

A. senegal gum and HIC-F1 fraction were dissolved at a concentration of $10 \mathrm{mg} \cdot \mathrm{ml}^{-1}$ in ultra pure deionised water $\left(18.2 \mathrm{~m} \Omega\right.$ resistivity) containing $0.02 \% \mathrm{NaN}_{3}$ and stirred overnight at room temperature. The $\mathrm{pH}$ was adjusted at 6.5 using a small aliquot of $\mathrm{NaOH}$ solution before to add pronase at a final concentration of $0.14 \mathrm{mg} \cdot \mathrm{ml}^{-1}$. The enzymatic hydrolysis occurred during $48 \mathrm{~h}$ at $35^{\circ} \mathrm{C}$. The enzymatic reaction was stopped by removing the pronase from the samples by centrifugation at 3000 rpm using a centricon Vivaspin 20 (cut-off of $50000 \mathrm{Da}$ ).

The hydrolysis products were also removed by the centrifugation step. The samples were then washed four times with ultra pure deionised water $(18.2 \mathrm{~m} \Omega$ resistivity) by centrifugation at 3000 rpm using a centricon Vivaspin 20 (cut-off of $50000 \mathrm{Da}$ ), before their freeze-drying.

\subsection{Preparation of Acacia senegal gum and its HIC fractions}

Stock solution of A. senegal gum and HIC fractions were dissolved in ultra pureultra-pure deionised water (18.2 $\mathrm{m} \Omega$ resistivity) and stirred overnight at room temperature. The solutions were centrifuged at $12500 \mathrm{rpm}$ for $30 \mathrm{~min}$ at $20^{\circ} \mathrm{C}$ to remove insoluble materials 
173 The electrophoretic mobility of A. senegal gum prepared in hydro-alcoholic solutions (tartaric

174 acid: 3 g. $\mathrm{L}^{-1}$; potassium sulfate: 1 g. $\mathrm{L}^{-1}$; ethanol: $12 \% \mathrm{v} / \mathrm{v}$ ) at $\mathrm{pH} 3.1,3.5$ and 4 was

175 determined using a Zetasizer 1000 (Malvern, United Kingdom). The measurements were

176 performed at $25^{\circ} \mathrm{C}$. The data are the average of three measurements.

177

178 2.5. Multi-detector high performance size exclusion chromatography

179 HPSEC experiments were performed using a Shimadzu HPLC system (Shimadzu, Kyoto,

180 Japan) coupled to one Shodex OHpak SB-G pre-column followed by four Shodex OHpak SB

181 columns in series (SB 806 HQ, SB 805 HQ, SB 804 HQ and SB 803 HQ). $50 \mu$ l of A. senegal

182 gum and HIC fractions solutions $\left(1 \mathrm{mg} \cdot \mathrm{ml}^{-1}\right)$ were injected. The elution was performed with

$1830.1 \mathrm{~mol} . \mathrm{L}^{-1} \mathrm{LiNO}_{3}$ solution containing $0.02 \% \mathrm{NaN}_{3}$ at a flow rate of $1 \mathrm{ml} \cdot \mathrm{min}^{-1}$ and $30^{\circ} \mathrm{C}$.

184 The HPSEC system was fitted in series to a Dawn Heleos II multi-angle laser light scattering

185 (Wyatt Technology Corp., Santa Barbara, Ca, USA) and an Optilab T-rEX refractometer

186 (Wyatt Technology Corp., Santa Barbara, Ca, USA). The molar mass distribution and the

187 weight-average molar mass $\left(\mathrm{M}_{\mathrm{w}}\right)$ were calculated using ASTRA software 6.1.1.17 (Wyatt

188 Technologies, Santa Barbara, CA). The data were analyzed using the Zimm's model $\left(1^{\text {st }}\right.$

189 order) and a refractive index increment $(\mathrm{dn} / \mathrm{dc})$ of $0.155,0.162,0.160$ and $0.145 \mathrm{ml} \cdot \mathrm{g}^{-1}$ for A.

190 senegal gum, HIC-F1, HIC-F2 and HIC-F3, respectively, as determined experimentally.

192 2.6. Colloidal stability of hydro-alcoholic - mineral solution

193 The hydro-alcoholic - mineral solution was prepared with ultra pureultra-pure deionised

194 water (18.2 $\mathrm{m} \Omega$ resistivity) according to the-International Oenological International Codex

195 (O.I.V.). This solution It-was composed of tartaric acid $\left(3\right.$ g.L $\left.\mathrm{L}^{-1}\right)$, potassium sulfate $\left(1 \mathrm{~g} . \mathrm{L}^{-1}\right)$,

196 ethanol $(12 \% \mathrm{v} / \mathrm{v})$, potassium ferrocyanide $\left(60 \mathrm{mg} \cdot \mathrm{L}^{-1}\right)$ and iron solution $\left(5 \mathrm{mg} \cdot \mathrm{L}^{-1} \%_{00}\right)$.

197 WhenThe addition of iron $\left(\mathrm{Fe}^{3+}\right)$ was added-to the hydro-alcoholic - mineral solution 
199 "Prussian blue" colloidal solution of $\mathrm{K}\left[\mathrm{Fe}^{\mathrm{III}} \mathrm{Fe}^{\mathrm{II}}(\mathrm{CN})_{6}\right]$-is obtained. The hydro-alcoholic 200 mineral solution was stirred during $2 \mathrm{~h}$ at room temperature before to adjust theits $\mathrm{pH}$ at 3.1 201 using $\mathrm{NaOH}$ solution $\left(1 \mathrm{~mol} \cdot \mathrm{L}^{-1}\right)$. The hydro-alcoholic - mineral solution was then filtered 202 through a $0.45 \mu \mathrm{m}$ regenerated cellulose membrane (GE Healthcare Life Sciences, Germany).

203 For the studies according to $\mathrm{pH}$, the hydro-alcoholic - mineral solution was prepared at $\mathrm{pH}$ $204 \quad 3.1,3.5$ and 4.0.

205 The hydro-alcoholic - mineral solution was destabilized by the addition of $\mathrm{CaCl}_{2}\left(22\right.$ g.L $\left.{ }^{-1}\right)$ 206 prepared in ultra-pure deionised water $\left(18.2 \mathrm{~m} \Omega\right.$ resistivity). The added $\mathrm{Ca}^{2+}$ bound to $207 \mathrm{~K}\left[\mathrm{Fe}^{\mathrm{III}} \mathrm{Fe}^{\mathrm{II}}(\mathrm{CN})_{6}\right]$ inducing the formation of "Prussian blue" precipitates $\left(\mathrm{Ca}\left[\mathrm{Fe}^{\mathrm{III}} \mathrm{Fe}^{\mathrm{II}}(\mathrm{CN})_{6}\right]_{2}\right)$. 208 Most of experiments were performed at a final $\mathrm{CaCl}_{2}$ concentration of $0.67 \mathrm{~g}$. $\mathrm{L}^{-1}$. Some 209 experiments were performed at a final concentration of $0.33,0.5,1$ and 1.33 g. $\mathrm{L}^{-1}$ to 210 investigate the influence of calcium. Each measurement was triplicated.

211 The efficiency of A. senegal gum and its HIC fraction to prevent the colloidal mineral 212 destabilization was studied by varying their concentration in the hydro-alcoholic - mineral 213 solution. The final concentration of A. senegal gum or its HIC fractions in the hydro-alcoholic 214 - mineral solution ranged between 0 and 1 g.L ${ }^{-1}$. A. senegal gum or HIC fraction solutions 215 were added to the hydro-alcoholic - mineral solution before the addition of $\mathrm{CaCl}_{2}$ solution. 216 Each measurement was triplicated.

218 2.7. Colloidal stability of hydro-alcoholic-grape marc solution and young red wine

219 The hydro-alcoholic - grape marc solution (wine-like medium) was prepared with ultra-pure 220 deionised water $\left(18.2 \mathrm{~m} \Omega\right.$ resistivity). It contained tartaric acid $\left(2.7\right.$ g. $\left.\mathrm{L}^{-1}\right)$, potassium sulfate 221 (0.9 g.L $\left.{ }^{-1}\right)$, grape marc powder $\left(3\right.$ g.L $\left.L^{-1}\right)$ and ethanol $(12 \%$ v/v). The solution was gently 222 stirred during $2 \mathrm{~h}$ at room temperature before to adjust the $\mathrm{pH}$ at 3.5 using $\mathrm{NaOH}$ solution (1 
223 mol. $\left.\mathrm{L}^{-1}\right)$. The solution was then filtered through a $0.45 \mu \mathrm{m}$ regenerated cellulose membrane

224 (GE Healthcare Life Sciences, Germany).

225 The colloidal destabilization of the hydro-alcoholic - grape marc solution and the young red

226 wine was induced by cooling the solutions to $10^{\circ} \mathrm{C}$. The efficiency of A. senegal gum and its

227 HIC fraction to prevent the destabilization of the hydro-alcoholic - grape marc solution and

228 the young red wine was studied at $10^{\circ} \mathrm{C}$ by varying their concentration between 0 and 2 g. $\mathrm{L}^{-1}$.

229 Each measurement was triplicated.

2.8. Characterization of the colloidal stability of hydro-alcoholic model solutions and young red wine

233 The colloidal stability of the hydro-alcoholic - mineral and hydro-alcoholic - grape marc 234 solutions, and the young red wine was investigated using a Turbiscan Tower equipped with a 235 pulsed near infrared light source $(\lambda=880 \mathrm{~nm})$ and two synchronous detectors, a transmission 236 (T) and a backscattering (BS) detectors (Formulaction, France). The samples were loaded into 237 cylindrical glass tubes and scanned throughout its entire height. The transmittance (T, in \%) 238 was measured every $1 \mathrm{~min}$ and $50 \mathrm{sec}$ during $24 \mathrm{~h}$ at $25^{\circ} \mathrm{C}$ for the hydro-alcoholic - mineral 239 solutions and during $48 \mathrm{~h}$ at $10^{\circ} \mathrm{C}$ for the hydro-alcoholic - grape marc solutions and young 240 red wine.

241 The transmittance $(\mathrm{T})$ profiles were analyzed using the TowerSoft software, version 1.1.0.36

242 (Formulaction, France). $\Delta \mathrm{T}(\%)$ corresponded to the difference in transmittance between the $243 \mathrm{scan}_{\mathrm{i}}$ and the first scan. The Turbiscan Stability Index (TSI) was also determined as the 244 following:

$$
T S I=\sum_{i} \frac{\sum h\left|\operatorname{scan}_{i}(h)-\operatorname{scan}_{i-1}(h)\right|}{H}
$$


The TSI corresponded to the transmittance variation at all measured position (h) throughout

247 the entire height $(\mathrm{H})$ of the sample between the $\operatorname{scan}_{i}$ and the $\operatorname{scan}_{i-1}$. The plot of TSI

248 according to time corresponds to the kinetic behavior of the samples that takes into account all

249 the physical phenomena (especially destabilization mechanism) occurring during the

250 measurement.

251 The TSI kinetics were used to plot the TSI values at $24 \mathrm{~h}$ in hydro alcoholic - mineral solution

252 and $48 \mathrm{~h}$ in hydro alcoholic - grape marc solution and young red wine according to AGPs

253 concentration. This representation assimilated to a "stability curve" was used to

254 experimentally determine the AGPs concentration, named critical concentration, necessary to

255 obtain the colloidal stability of the solutions.

\section{Results}

3.1. Colloidal stabilization mechanism of the hydro-alcoholic - mineral solution by A. senegal gum

The colloidal stability of the hydro-alcoholic - mineral solution ( $\mathrm{pH} 3.1$ ) containing A. senegal gum was followed by measuring at $25^{\circ} \mathrm{C}$ the transmittance $(\mathrm{T})$ of the solutions during 24h using a light scattering equipment. The figure 1 showed the temporal change in transmittance $(\Delta \mathrm{T})$ of three hydro-alcoholic - mineral solutions without and with 0.09 and hydro-alcoholic - mineral solutions without and with 0.09 g.L $\mathrm{L}^{-1}$ of A. senegal gum increased respectively by $60 \%$ and $35 \%$ in the middle of the sample (cell height: $2-36 \mathrm{~mm}$ ) reflecting a clarification of the solution. This phenomenon was confirmed by the loss of the blue color of the solutions after $24 \mathrm{~h}$ (Figure 1A and 1B). The clarification resulted from the formation of a salt precipitate $\left(\mathrm{Ca}\left[\mathrm{Fe}^{\mathrm{III}} \mathrm{Fe}^{\mathrm{II}}(\mathrm{CN})_{6}\right]_{2}\right)$ between $\mathrm{K}\left[\mathrm{Fe}^{\mathrm{III}} \mathrm{Fe}^{\mathrm{II}}(\mathrm{CN})_{6}\right]$ and $\mathrm{Ca}^{2+}$ that pelleted, as evidenced by the decrease of $\mathrm{T}$ by $5 \%$ and $2 \%$ after $24 \mathrm{~h}$ in the bottom of the cell (cell height: 
$271 \quad 1-1.5 \mathrm{~mm}$ ) for the solutions without and with $0.09 \mathrm{~g} . \mathrm{L}^{-1}$ of A. senegal gum, respectively

272 (Figure 1A and 1B). On the other hand, the transmittance of the hydro-alcoholic - mineral

273 solution containing 0.14 g.L $\mathrm{L}^{-1}$ of A. senegal gum was constant during the $24 \mathrm{~h}$ of

274 measurement, reflecting the colloidal stability of the solution. The influence of A. senegal

275 gum concentration $\left(0-0.14\right.$ g. $\left.\mathrm{L}^{-1}\right)$ on the colloidal stability kinetics of the hydro-alcoholic -

276 mineral solution was analyzed by plotting the TSI (Turbiscan Stability Index) according to

277 time (Figure 2A). The increase of A. senegal gum concentration reduced and delayed the

278 instability mechanism occurring in the hydro-alcoholic - mineral solution. The colloidal

279 instability was totally prevented for an A. senegal gum concentration above around 0.11 g.L. $\mathrm{L}^{-1}$.

280 The minimal A. senegal gum concentration ([AG $]_{\text {critical }}$ ) necessary to obtain the hydro-

281 alcoholic - mineral colloidal stability was determined by plotting the TSI values after $24 \mathrm{~h}$

282 according to A. senegal gum concentration (stability curve) (Figure 2B). Below an A. senegal

283 gum concentration of 0.05 g. $\mathrm{L}^{-1}$, the TSI values at $24 \mathrm{~h}$ was constant and similar to the control

284 sample without A. senegal gum. In these experimental conditions, the concentration of A.

285 senegal gum was too low. Above 0.05 g.L $\mathrm{L}^{-1}$ of A. senegal gum, the TSI values decreased

286 progressively before to reach a constant TSI value $(\leq 2)$ similar to the control without $\mathrm{Ca}^{2+}$ for

287 A. senegal gum concentration upper than 0.11 g. $\mathrm{L}^{-1}$. Based on the stability curve, the

$288[\text { AG }]_{\text {critical was }} 0.114 \pm 0.002$ g.L - $^{-1}$ (Figure 2B).

289 The colloidal stabilization mechanism was further investigated by modifying the

290 physicochemical condition as the $\mathrm{pH}$ of the solutions and the amount of $\mathrm{Ca}^{2+}$ added to induce

291 the colloidal instability mechanism. The stability curves of hydro-alcoholic - mineral

292 solutions prepared at $\mathrm{pH} 3.1,3.5$ and 4.0 are shown in Figure 3A. As the $\mathrm{pH}$ increased from

2933.1 to 4.0 , the stability curves were shifted towards lower A. senegal gum concentrations

294 necessary to prevent the colloidal instability. The $[\mathrm{AG}]_{\text {critical }}$ were $0.114 \pm 0.002,0.094 \pm$

2950.003 and $0.064 \pm 0.002$ g. $\mathrm{L}^{-1}$ at $\mathrm{pH} 3.1,3.5$ and 4.0, respectively. Hence, the colloidal 
stabilizing properties of A. senegal gum were greatly influenced by $\mathrm{pH}$ and enhanced with its increase in this $\mathrm{pH}$ range. AGPs from A. senegal gum are weakly charged glycoproteins characterized by a global negative charge in aqueous solution for $\mathrm{pH}$ ranging from 2.0 to 10.0 in aqueous solutions reflecting the increase of the global negative charge (Burgess \& Carless, 1984; Schmitt, Sanchez, Thomas \& Hardy, 1999). Thus, the electrophoretic mobility $\left(\mu_{\mathrm{E}}\right)$ of

302 A. senegal gum in hydro-alcoholic solutions prepared at $\mathrm{pH} 3.1,3.5$ and 4.0 was measured and plotted according to $[\mathrm{AG}]_{\text {critical }}$ (Figure 3B). A good correlation was evidenced between

A. senegal gum $\mu_{\mathrm{E}}$ and its concentration necessary to stabilize the hydro-alcoholic - mineral solutions. The more the negative A. senegal gum $\mu_{\mathrm{E}}$ was, the less the A. senegal gum quantity was required to prevent the colloidal instability. Hence, negative charges carried by AGPs were certainly involved in this colloidal stabilization mechanism.

Since the colloidal instability of the hydro-alcoholic - mineral solution is induced by the addition of $\mathrm{Ca}^{2+}$, it was hypothesized that electrostatic interactions between $\mathrm{Ca}^{2+}$ and negative charges of AGPs could play an important role in the stabilization mechanism. Therefore, we determined the $[\mathrm{AG}]_{\text {critical }}$ in hydro-alcoholic - mineral solutions $(\mathrm{pH} 3.1)$ containing different

312 final $\mathrm{Ca}^{2+}$ concentrations $\left(0.33\right.$ to $\left.1.33 \mathrm{~g} \cdot \mathrm{L}^{-1}\right)$. A close linear relationship between the $313[\mathrm{AG}]_{\text {critical }}$ and the amount of $\mathrm{Ca}^{2+}$ added in the hydro-alcoholic - mineral solutions was 314 obtained (Figure 4). The increase of $\mathrm{Ca}^{2+}$ concentration induced also the increase of $315[\mathrm{AG}]_{\text {critical }}$. Based on its structural and physicochemical properties, hyperbranched and 316 negatively charged, AGPs from A. senegal gum appear as a natural mineral carrier that 317 contains $-23.4 \mathrm{wt} \%$ of ash for this Acacia gum sample, and especially $\mathrm{Ca}^{2+}$ (Anderson, 318 Douglas, Morrison \& Weiping, 1990; Debon \& Tester, 2001; Mhinzi, 2003). Lamport and 319 Varnai evidenced that $\mathrm{Ca}^{2+}$ bound to AGPs with a fairly strong binding constant of $6.5 \times 10^{-6}$ 320 mol. $\mathrm{L}^{-1}$ (Lamport \& Varnai, 2013). They also showed that the $\mathrm{Ca}^{2+}$ binding sites of AGPs 
were not naturally fully saturated by $\mathrm{Ca}^{2+}$. Hence, as expected, we can easily suggest that AGPs stabilized the hydro-alcoholic - mineral solutions by its electrostatic binding with $\mathrm{Ca}^{2+}$, the driver of the instability mechanism.

\subsection{Identification AGPs from A. senegal gum involved in the colloidal stability mechanism of} the hydro-alcoholic-mineral solution

As previously mentioned, A. senegal gum is a continuum of AGPs differing by their biochemical, structural and physicochemical properties (Randall et al., 1989; Renard et al., 2006). To better identify the macromolecules involved in this colloidal stabilization mechanism, A. senegal gum was fractionated using Hydrophobic Interaction Chromatography (HIC). The three fractions obtained were named HIC-F1, HIC-F2 and HIC-F3 according to their elution order and consequently to their increasing hydrophobic index. The biochemical composition and some structural properties of A. senegal gum and its HIC fractions were previously described (Mejia-Tamayo et al., 2018) and presented in supplementary data (table 1). The three HIC fractions are composed of the same sugars (D-galactose, L-arabinose, Dglucuronic acid and 4-O-methyl-D-glucuronic acid) with some differences in their proportions. The arabinose to galactose (Ara/Gal) molar ratio was $0.69,1.03$ and 1.29 for HIC-F1, HIC-F2 and HIC-F3, respectively. HIC-F1was also richer in uronic acid (glucuronic and 4-O-methyl-glucuronic acids) than HIC-F2 and HIC-F3 fractions (21.7 wt\% vs. $16.2 \mathrm{wt} \%$ and $14.4 \mathrm{wt} \%$, respectively). Hence, the carbohydrate blocks of HIC-F1 were supposed to carry more negative charges than HIC-F2 and HIC-F3 ones. Biochemically, the main difference between HIC fractions was the protein content and consequently the protein/sugar ratio. HIC-F3 showed a higher amount of proteins $(13.8 \mathrm{wt} \%)$ and then protein/sugar ratio (0.169) as compared to HIC-F2 (6.3 wt\% and 0.069) and HIC-F1 (0.5 wt\% and 0.005). Structurally, the three HIC fractions differed mainly by their mean molar mass $\left(\mathrm{M}_{\mathrm{w}}\right)$ and high 
346 molar mass $\left(\mathrm{HM}_{\mathrm{w}}\right)$ macromolecules content $\left(\mathrm{M}_{\mathrm{w}}>10^{6} \mathrm{~g} \cdot \mathrm{mol}^{-1}\right)$. HIC-F2 and HIC-F3 were

347 richer in protein-rich high molar mass $\left(\mathrm{HM}_{\mathrm{w}}\right)$ AGPs than HIC-F1 (73, 56 and 3\%,

348 respectively) (supplementary table 1).

349 The stability curves of the hydro-alcoholic - mineral solution in the presence of the three HIC

350 fractions are shown in the Figure 5. They can be classified from the most effective to the least

351 in terms of stabilization as: HIC-F3 > HIC-F2 > HIC-F1. Thus, the critical concentrations of

352 HIC-F1, HIC-F2 and HIC-F3 fractions were $0.570,0.090$ and 0.012 g.L ${ }^{-1}$, respectively.

353 Though HIC-F3 was the minor fraction in weight (around $1 \mathrm{wt} \%$ of whole A. senegal gum),

354 its efficiency for the colloidal stabilization of the hydro-alcoholic - mineral solution was 48 ,

35510 and 7.5 times larger than those of HIC-F1, A. senegal gum and HIC-F2, respectively.

356 Hence, the colloidal stability properties of A. senegal gum towards the hydro-alcoholic -

357 mineral solution were mainly due to its two minor fractions in weight, HIC-F2 and HIC-F3

358 (around $11 \mathrm{wt} \%$ of whole A. senegal gum), that were especially richer in protein-rich $\mathrm{HM}_{\mathrm{w}}$

359 AGPs than HIC-F1 (Table 1).

360 HIC-F1 (89 wt\% of whole A. senegal gum) that was characterized by poor colloidal 361 stabilizing property contained also a low amount (3\%) of protein-rich $\mathrm{HM}_{\mathrm{w}}$ AGPs. To precise 362 whether the macromolecular origin of the colloidal stabilizing properties is due to this 363 fraction, its $\mathrm{HM}_{\mathrm{w}}$ AGPs were removed by an enzymatic hydrolysis treatment using the 364 pronase, a protease mixture. Several studies showed the specific hydrolysis activity of pronase 365 for protein-rich $\mathrm{HM}_{\mathrm{w}}$ AGPs from A. senegal gum without degrading and affecting the 366 structural properties of low $\mathrm{M}_{\mathrm{w}}\left(\mathrm{LM}_{\mathrm{w}}\right)$ AGPs (Connolly, Fenyo \& Vandevelde, 1988; Randall 367 et al., 1989; Flindt, Al-Assaf, Phillips \& Williams, 2005; Mahendran, Williams, Phillips, Al368 Assaf \& Baldwin, 2008; Renard, Lavenant-Gourgeon, Lapp, Nigen \& Sanchez, 2014). The 369 refractive index (RI) signal and the $\mathrm{M}_{\mathrm{w}}$ distribution of HIC-F1 before and after the enzymatic 370 treatment are shown in Figure 6A. The pronase hydrolyzed the protein-rich AGPs decreasing 
the $\mathrm{HM}_{\mathrm{w}}$ AGPs content from 3 to $1.7 \%$, without affecting the quantity and the structural

372 properties of $\mathrm{LM}_{\mathrm{w}}$ AGPs (Figure 6A). The colloidal stabilizing properties of the hydrolyzed

373 HIC-F1 towards the hydro-alcoholic - mineral solution were characterized and compared to

374 HIC-F1 (Figure 6C). The hydro-alcoholic - mineral solutions was totally unstable until 1.2

375 g.L $\mathrm{L}^{-1}$ of hydrolyzed HIC-F1, a concentration twice more than the minimal HIC-F1

376 concentration necessary to totally prevent the colloidal instability $\left([\mathrm{HIC}-\mathrm{F} 1]_{\text {critical }}=0.570 \mathrm{~g} . \mathrm{L}^{-}\right.$

$377^{1}$ ). Hence, the removal of less than $1.5 \%$ of AGPs from HIC-F1, corresponding to $\mathrm{HM}_{\mathrm{w}}$

378 AGPs, induced the loss of its colloidal stabilizing properties. The main contribution of

379 protein-rich $\mathrm{HM}_{\mathrm{w}}$ AGPs was also confirmed by studying the colloidal stabilizing properties of

380 hydrolyzed A. senegal gum by pronase. After the enzymatic treatment, the content of protein381 rich $\mathrm{HM}_{\mathrm{w}}\left(\mathrm{M}_{\mathrm{w}}>10^{6} \mathrm{~g} \cdot \mathrm{mol}^{-1}\right)$ AGPs decreased from 14 to $6 \%$ (Figure 6B). As observed for

382 HIC-F1, A. senegal gum also lost its stabilizing properties after the pronase treatment: the 383 hydro-alcoholic - mineral solutions containing 0.12 g.L $\mathrm{L}^{-1}$ of hydrolyzed A. senegal gum was 384 totally unstable while $[\mathrm{AG}]_{\text {critical }}$ was found to be $0.114 \mathrm{~g} . \mathrm{L}^{-1}$. These results highlighted the 385 major role of the protein-rich AGPs in the colloidal stabilizing mechanism of the hydro386 alcoholic - mineral solution. Hence, HIC-F2 and HIC-F3 fractions prevented the colloidal 387 instability of the hydro-alcoholic - mineral solution (i.e. formation of salt precipitates) by 388 their electrostatic binding with $\mathrm{Ca}^{2+}$. The key role of the protein-rich AGPs on the functional 389 properties of A. senegal gum was also evidenced by studying its interfacial properties 390 (Elmaman, Al-Assaf, Phillips \& Williams, 2008). In this study, the removal of the protein391 rich AGPs by a pronase treatment resulted in the loss of the interfacial properties of $\mathrm{A}$. 392 senegal gum. red wine by AGPs from A. senegal gum 
In order to correlate the results obtained on the hydro-alcoholic - mineral solution to the wine matrix, the stabilizing properties of A. senegal gum and its HIC fractions were characterized on an unstable synthetic hydro-alcoholic - grape marc solution (wine-like medium) and an 399 unstable young red wine.

400 The hydro-alcoholic - grape marc solution and the young red wine that were stable at $25^{\circ} \mathrm{C}$ 401 (control sample) were destabilized upon cooling to $10^{\circ} \mathrm{C}$ that induced the precipitation of the 402 unstable colloidal substances as the coloring matter (Ribereau-Gayon et al., 2006; Alcade-Eon 403 et al., 2014). The colloidal stability kinetics of the hydro-alcoholic - grape marc solution and 404 the young red wine supplemented with A. senegal gum and HIC fractions were followed by 405 measuring the transmittance of the solution during $48 \mathrm{~h}$ at $10^{\circ} \mathrm{C}$. The increase of A. senegal 406 gum concentration from 0 to 0.5 g. $\mathrm{L}^{-1}$ led to the colloidal stabilization of the hydro-alcoholic 407 - grape marc solution (Figure 7A). The solution supplemented with 0.5 g.L.1 of A. senegal 408 gum presented a similar kinetic behavior as the control sample at $25^{\circ} \mathrm{C}$ suggesting that AGPs from A. senegal gum totally prevented the colloidal instability. This result was in agreement with the use of A. senegal gum, and more globally the AGPs, as protective colloids in wines and model beverages to prevent the aggregation and precipitation of polyphenols and proteins

412 (Ribereau-Gayon et al., 2006; Waters et al., 1994; Riou et al., 2002; Mateus et al., 2004; 413 Luck, Liao, Murray, Grimmer, Warminski, Williamson, Lilley \& Haslam, 1994; Liang, Liu, 414 Qi, Su, Yu, Wang \& He, 2013; Soares et al., 2009; de Freitas et al., 2003), and the chemical 415 modifications of anthocyanins (Chung et al., 2016). The efficiency of A. senegal gum and its 416 HIC fractions towards the colloidal instability of this hydro-alcoholic - grape marc solution 417 were characterized by plotting the stability curves after $48 \mathrm{~h}$ of kinetics (Figure $7 \mathrm{~B}$ ). The 418 critical concentrations of A. senegal gum, HIC-F1, HIC-F2 and HIC-F3 fractions were found 419 to be $0.245 \pm 0.010,0.996 \pm 0.090,0.118 \pm 0.014$ and $0.027 \pm 0.003$ g. $\mathrm{L}^{-1}$, respectively. The colloidal stabilizing properties of A. senegal gum, HIC-F2 and HIC-F3 fractions were also 
421

422

426

427

436

confirmed on an unstable young red wine (Figure 7C). They totally prevented the young red wine colloidal instability at $10^{\circ} \mathrm{C}$ for concentrations of $0.086 \pm 0.007,0.045 \pm 0.006$ and $0.015 \pm 0.002$ g. $\mathrm{L}^{-1}$, respectively. Unlike the other two HIC fractions, HIC-F1 was not efficient for the colloidal stabilization of the young red wine even at a concentration of 2 g. $\mathrm{L}^{-1}$ (data not shown).

\section{Discussion}

The colloidal stabilizing properties of A. senegal gum and its HIC fractions isolated from Hydrophobic Interaction Chromatography were investigated on three colloidal hydroalcoholic matrices: a hydro-alcoholic - mineral matrix, a hydro-alcoholic - grape marc solution ("wine-like" matrix) and an unstable young red wine. Whatever the hydro-alcoholic matrix tested, the HIC fractions can be classified in the same following order according to their colloidal stabilizing efficiency: HIC-F1 $<$ HIC-F2 < HICF3. A. senegal gum that is a mixture of the HIC fractions presented some intermediate properties between those of HIC-F1 and HIC-F2. Before its addition in young red wines, Ustally, A. senegal gum added in young red wines-is usually chosen based on its ability to stabilize a hydro-alcoholic - mineral matrix.

When we plot the critical concentrations of A. senegal gum and its HIC fractions determined in hydro-alcoholic - mineral solution as a function of those determined in hydro-alcoholic grape marc solution or young red wine (Figure 8), a good correlation between both systems is obtained. The more the AGPs from A. senegal gum are efficient to stabilize the hydroalcoholic - mineral solution, the better they are to stabilize the polyphenols in young red wines. Hence, these results confirmed and strengthened the relevance and the use of the hydro-alcoholic - mineral test for the evaluation of A. senegal gum colloidal stabilizing properties before its addition in young red wine. 
445 In the hydro-alcoholic - mineral solution, the colloidal stability was assessed by the

446 electrostatic binding of $\mathrm{Ca}^{2+}$, the "positively charged" driver of the colloidal instability, with

447 the negatively charged AGPs. According to the monosaccharide and amino acid compositions

448 of Acacia senegal gum (Mejia-Tamayo et al., 2018), the negative charges of AGPs are carried

449 out both by the carbohydrate moiety through the carboxylic groups of glucuronic and 4-O-

450 methyl glucuronic acid monosaccharides, and the polypeptidic backbone by the carboxylic

451 groups of aspartic and glutamic acid amino acid side chains. The content and proportion of

452 these negatively charged uronic acids and amino acids are fraction dependent with a large

453 excess of uronic acids in the three fractions. HIC-F1 has a higher uronic acid content (20.9

454 wt\% of whole fraction) as compared to HIC-F2 and HIC-F3 (14.9 wt\% and 11.7 wt\%,

455 respectively) (supplementary table 1). Recently, Grein-Iankovski et al. (2018) characterized

456 an acid dissociation constant $\left(\mathrm{pK}_{\mathrm{a}}\right)$ between 3 and 4 for the AGPs from A. senegal gum that

457 was attributed to the carboxylic group of glucuronic acids. This chemical property suggests a

458 partial ionization of the carboxylic groups in the range of the $\mathrm{pH}$ studied in the hydro-

459 alcoholic solutions, and moreover the increase of the negative charge of AGPs with the

460 increase of $\mathrm{pH}$ from 3.1 to 4.0. This result is in well accordance with the decrease of the

461 critical concentration of A. senegal gum when the $\mathrm{pH}$ is increased from 3.1 to 4.0. Recently,

462 tThe binding of $\mathrm{Ca}^{2+}$ with the carboxyl group of two uronic acids of a conserved O-Hyp-

463 linked arabinogalactan polysaccharide was demonstrated using molecular dynamic

464 simulations (Lamport \& Varnai, 2013). Hence, based on the excess of uronic acid in the three

465 HIC fractions and the molecular dynamic simulations it could be expected as a first

466 approximation that the mineral colloidal stability occurred mainly by the binding of $\mathrm{Ca}^{2+}$ to

467 the uronic acids of carbohydrate blocks. However, our results showed that HIC-F1, the richest

468 fraction in uronic acids, had the weakest colloidal stabilizing properties, while HIC-F3, the

469 one with the least uronic acids content, was the most effective fraction for the colloidal 
470

471

473

474

475

476

477

478

479

480

481

482

483

484

485

486

487

488

489

490

491

492

493

494

stabilization of the hydro-alcoholic - mineral solution (Figure 5). Hence, the stabilizing properties of AGPs could not be only explained by their uronic acids content. We also showed a significant decrease of the stabilizing properties of HIC-F1 and A. senegal gum after the hydrolysis of their protein-rich AGPs by a pronase treatment. The pronase is a cocktail of proteases hydrolyzing the accessible polypeptidic backbone of protein-rich AGPs without degrading the low molar mass $\left(\mathrm{LM}_{\mathrm{w}}\right)$ AGPs poor in proteins (Renard et al. 2014). This enzymatic treatment gave rise to macromolecules presenting similar molar masses $\left(\mathrm{M}_{\mathrm{w}}\right.$ from 1.8 to $6.0 \times 10^{5}$ g.mol ${ }^{-1}$ ) and conformational properties as low molar mass $\left(\mathrm{LM}_{\mathrm{w}}\right)$ AGPs naturally found in A. senegal gum (Connolly et al., 1988, Randall et al., 1989, Aoki, AlAssaf, Katayama \& Phillips, 2007, Renard et al., 2014). Since the conformational properties, and probably the sugar organization, of the released carbohydrate blocks of AGPs was seemingly not disturbed by the pronase treatment, this suggested that the uronic acids of the carbohydrate blocks were certainly not directly involved in the electrostatic $\mathrm{Ca}^{2+}$ binding in this colloidal stability test. Similar results were obtained on AGPs purified from a red wine by Waters et al. These authors showed that the greatest protein haze protective activity in Chardonnay wine was reached with AGPs presenting the highest protein content. Moreover, this protective activity was not affected by the sugar hydrolysis of AGPs using $\alpha$ arabinofuranosidase and endo-( $(1 \rightarrow 6)-\beta$-D-galactanase, while it was totally lost when the protein moiety was altered with the loss of $75 \%$ of initial protein after smith degradation treatment (Waters et al., 1994). These results revealed the key role of the accessible polypeptidic backbone of AGPs in their colloidal stabilizing properties. In the hydro-alcoholic - mineral solution, it could be hypothesized that the electrostatic binding of $\mathrm{Ca}^{2+}$ occurred with only the negatively charged amino acids (aspartic and glutamic acids) or with the involvement of both negatively charged amino acids and uronic acid monosaccharides localized close to the protein backbone. 
As observed in the hydro-alcoholic - mineral solution, the protein-rich AGPs from A. senegal

496

497

498

499

500

501

502

503

504

505

506

507

508

509

510

511

512

513

514

515

516

517

518

519

gum, HIC-F2 and HIC-F3 fractions, were also found to be the most effective for the colloidal stabilization of the hydro-alcoholic - grape marc solution and the unstable young red wine.

The surface and colloidal stabilizing properties of the protein-rich AGPs were previously demonstrated in other type of matrices. After A. senegal gum fractionation by size exclusion chromatography (SEC) and hydrophobic interaction chromatography (HIC), Ray et al. showed that the protein-rich AGPs made the best emulsions in model beverage (Ray, Bird, Iacobucci \& Clark, 1995). Protein-rich AGPs were also found to be the most effective in decreasing the interfacial tension of n-hexadecane-water interface (Castellani, Al-Assaf, Axelos, Phillips \& Anton, 2010), to preferentially adsorb at the interface of latex dispersions (Snowden, Phillips \& Williams, 1987) and oil droplets (Randall, Phillips \& Williams, 1988), and to stabilize carbon nanotube dispersions (Li, Zhang, Jin \& Cai, 2018).

The stabilizing properties of the protein-rich AGPs towards such a chemical diversity of molecules (minerals, polyphenols, proteins, oils, latex, etc...) could be relied to their intrinsic properties. Structurally, the three HIC fractions seems not so different. AGPs from these fractions are hyperbranched glycoproteins adopting more or less extended ellipsoidal conformations (Sanchez, Schmitt, Kolodziejczyk, Lapp, Gaillard \& Renard, 2008; Renard, Garnier, Lapp, Schmitt \& Sanchez, 2012; Renard, Garnier, Lapp, Schmitt \& Sanchez, 2013; Renard et al., 2014; Lopez-Torrez et al., 2015). AGPs from HIC-F2 and HIC-F3 fractions also appeared as more "flexible" than those of HIC-F1 (Mejia-Tamayo et al., 2018). Biochemically, HIC fractions presented some more marked differences, especially in their protein content and consequently in their protein to sugar ratio (supplementary table 1) that influenced their hydrophobic and hydration properties (Mejia-Tamayo et al., 2018). HIC-F1, HIC-F2 and HIC-F3 were eluted in that order according to their protein content and increasing hydrophobic behavior. From our results, the higher the HIC fraction is rich in 
520 protein, the more effective it is for the colloidal stabilization of the three hydro-alcoholic

521 solutions. In the hydro-alcoholic - grape marc solution and young red wine, these results were

522 in accordance with the putative stabilization of polyphenols by their binding with AGPs via

523 the establishment of hydrophobic interactions and hydrogen bonding (de Freitas et al., 2003;

524 Mateus et al., 2004; Soares et al., 2009; Soares et al., 2012; Chung et al., 2016). Hence, the

525 protein content and certainly the amino acids composition and distribution in the protein

526 backbone of AGPs from A. senegal gum appeared as the main factor for the expression of

527 their colloidal stabilizing properties in hydro-alcoholic matrices. This behavior agrees with

528 the work performed by Dickinson et al. dealing with the surface properties of Acacia gums.

529 Based on the surface activity of various Acacia gums with different protein content, these

530 authors previously evidenced a good correlation between the Acacia gum protein content and

531 its interfacial properties (Dickinson, Murray, Stainsby \& Anderson, 1988; Dickinson, 2003).

532 The protein content appeared also as essential for the colloidal stabilizing properties of

533 mannoproteins, other glycoproteins considered as protective colloids in wine. The addition of

534 mannoproteins containing a high proportion of proteins (10 to $30 \%$ ) to red wine prevented the

535 coloring matter precipitation and protein haze in white wine (Waters et al., 1994a; Escot et al.,

536 2001; Charpentier, Escot, Gonzalez, Dulau \& Feuillat, 2004; Poncet et al., 2007), while the

537 mannoproteins with a low protein content were devoid of protective activity (Charpentier et

538 al., 2004; Guadalupe, Palacios \& Ayestaran, 2007; Poncet et al., 2007; Guadalupe \&

539 Ayestaran, 2008).

540 It is useful to remember that AGPs are constituted by a protein backbone covalently linked to

541 hyperbranched carbohydrate blocks that partially hindered it from its environment. Therefore,

542 if we consider the protein as the major component for the colloidal stabilizing properties of

543 AGPs, it would seem appropriate to consider not only the protein content but also its

544 accessibility to its environment that is closely link to the rate of glycosylation. HIC-F1, 
545 presenting the weakest colloidal stabilizing properties, is highly glycosylated as compared to

546 HIC-F2 and HIC-F3: their protein to sugar ratios (w/w) were 0.005, 0.069 and 0.169 ,

547 respectively. The high glycosylation rate of HIC-F1 cause the protein less accessible to its

548 environment as demonstrated by its resistance to the protein hydrolysis assay (Flindt et al.,

549 2005; Renard et al., 2014). Moreover, the rate of glycosylation also influenced the structural

550 and physicochemical properties of HIC fractions. The more the AGPs were glycosylated, then

551 hydrated, the less their flexibility and hydrophobic behavior were marked (Mejia Tamayo et

552 al., 2018). Therefore, we can advance that the surface properties of AGPs are mainly due to

553 the physicochemical properties of their protein backbone which are subtly modulated and

554 controlled by their rate of glycosylation.

555

\section{5. Conclusion}

557 In this research, the colloidal stabilizing properties of arabinogalactan-proteins from A. senegal gum in hydro-alcoholic - mineral and hydro-alcoholic - polyphenols solutions were investigated. The AGPs prevented the colloidal instability of both calcium iron

560 hexacyanoferrate salts in "model" hydro-alcoholic solution and polyphenols in young red

561 wine. A good relationship was evidenced between the stabilizing properties of AGPs 562 determined in these two hydro-alcoholic solutions. The protein moiety of the AGPs appeared 563 to be essential for these functional properties whatever the hydro-alcoholic solutions. The 564 more the AGPs were rich in proteins, the more their colloidal stabilizing efficiency were. In 565 the hydro-alcoholic - mineral solution, the AGPs avoided the precipitation of potassium 566 ferrocyanide salts by their electrostatic binding with $\mathrm{Ca}^{2+}$, the driver of the instability.

\section{Acknowledgements}


The authors would like to thank BioLaffort Company (Bordeaux, France) for the financial support and Alland\&Robert Company (Port-Mort, France) for the gift of Acacia senegal gum sample.

\section{References}

574 Akiyama, Y., Eda, S., \& Kato K. (1984). Gum Arabic is a kind of arabinogalactan protein.

575 Agricultural and Biological Chemistry, 48, 235-237.

576 Alcade-Eon, C., Garcia-Estévez, I., Puente, V., Rivas-Gonzalo, J.C., \& Escribano-Bailon, 577 M.T. (2014). Color stabilization of red wines. A chemical and colloidal approach. Journal of 578 Agricultural and Food Chemistry, 62, 6984-6994.

579 Anderson, D.M.W., Hirst, E., \& Stoddart, J.F. (1966). Studies on uronic acid materials Part

580 XVII some structural features of Acacia senegal gum (gum Arabic). Journal of the Chemical 581 Society C: Organic, 1959-1966.

582 Anderson, D.M.W., \& Stoddart, J.F. (1966). Studies on uronic acid materials Part XV. The 583 use of molecular-sieve chromatography in studies on Acacia senegal gum (Gum Arabic).

\section{Carbohydrate Research, 2, 104-114.}

585 Anderson, D.M.W., Douglas, D.M.B., Morrison, N.A., \& Weiping, W. (1990). Specifications 586 for gum Arabic (Acacia senegal); analytical data for samples collected between 1904 and 587 1989. Food Additives and Contaminants, 7, 303-321.

588 Aoki, H., Al-Assaf, S., Katayama, T., \& Phillips, G.O. (2007). Characterization and properties 589 of Acacia senegal (L.) Willd. Var. senegal with enhanced properties (Acacia (sen) SUPER 590 GUM (TM): Part 2- Mechanism of the maturation process. Food Hydrocolloids, 21, 329-337. 591 Burgess, D.J., \& Carless, J.E. (1984). Microelectrophoretic studies of gelatin and Acacia for 592 the prediction of complex coacervation. Journal of Colloid and Interface Science, 98, 1-8. 
593 Castellani, O., Al-Assaf, S., Axelos, M., Phillips, G.O., \& Anton, M. (2010). Hydrocolloids

594 with emulsifying capacity. Part-2 Adsorption properties at the n-hexadecane-water interface.

595 Food Hydrocolloids, 24, 121-130.

596 Charpentier, C., Escot, S., Gonzalez, E., Dulau, L., \& Feuillat, M. (2004). Influence of yeast 597 glycosylated proteins on tannins aggregation in model solution. Journal International des 598 Sciences de la Vigne et du Vin, 38, 209-218.

599 Chung, C., Rojanasasithara, T., Mutilangi, W., \& McClements, D.J. (2016). Enhancement of 600 colour stability of anthocyanins in model beverages by gum Arabic addition. Food Chemistry, $601201,14-22$.

602 Connolly, S., Fenyo, J.C., \& Vandevelde, M.C. (1988). Effect of a proteinase on the 603 macromolecular distribution of Acacia senegal gum. Carbohydrate Polymers, 8, 23-32.

604 Debon, S.J.J., \& Tester, R.F. (2001). In vitro binding of calcium, iron and zinc by non-starch 605 polysaccharides. Food Chemistry, 73, 401-410.

606 Dickinson, E., Murray, B.S., Stainsby, G., \& Anderson, D.M.W. (1988). Surface activity and 607 emulsifying behavior of some Acacia gums. Food Hydrocolloids, 2, 477-490.

608 Dickinson, E. (2003). Hydrocolloids at interfaces and the influence on the properties of 609 dispersed systems. Food Hydrocolloids, 17, 25-39.

610 de Freitas, V., Carvalho, E., \& Mateus, N. (2003). Study of carbohydrate influence on protein611 tannin aggregation by nephelometry. Food Chemistry, 81, 503-509.

612 Dupin, I.V.S., Stockdale, V.J., Williams, P.J., Jones, G.P., Markides, A.J., \& Waters, E.J. 613 (2000). Saccharomyces cerevisiae mannoproteins that protect wine from protein haze:

614 evaluation of extraction methods and immunolocalization. Journal of Agricultural and Food 615 Chemistry, 48, 1086-1095. 
616 Elmaman, M., Al-Assaf, S., Phillips, G.O., \& Williams, P.A. (2008). Studies on Acacia

617 exudate gums: Part VI. Interfacial rheology of Acacia senegal and Acacia seyal. Food

618 Hydrocolloids, 22, 682-689.

619 Escot, S., Feuillat, M., Dulau, L., \& Charpentier, C. (2001). Release of polysaccharides by

620 yeasts and the influence of released polysaccharides on colour stability and wine astringency.

621 Australian Journal of Grape and Wine research, 7, 153-159.

622 Flindt, C., Al-Assaf, S., Phillips, G.O., \& Williams, P.A. (2005). Studies on Acacia exudate

623 gums: Part V. Structural features of Acacia seyal. Food Hydrocolloids, 19, 687-701.

624 Gerbaud, V., Gabas, N., Blouin, J., \& Crachereau, J.C. (2010). Stuy of wine acid salt

625 stabilization by addition of carboxymethylcellulose (CMC) : comparison with the «protective

626 colloids » effect. Journal International des Sciences de la Vigne et du Vin, 44, 231-242.

627 Gordillo, B., Cejudo-Bastante, M.J., Rodríguez-Pulido, F.J., Jara-Palacios, M.J., Ramírez-

628 Pérez, P., González-Miret, M.L., \& Heredia, F.J. (2014) Impact of adding white pomace to

629 red grapes on the phenolic composition and color stability of syrah wines from a warm

630 climate. Journal of Agricultural and Food Chemistry, 62, 2663-2671.

631 Grein-Iankovski, A., Ferreira, J.G.L., Orth, E.S., Sierakowski, M.R., Cardoso, M.B., Simas,

632 F.F., \& Riegel-Vidotti, I.C. (2018). A comprehensive study of the relation between structural

633 and physical chemical properties of acacia gums. Food Hydrocolloids, 85, 167-175.

634 Guadalupe, Z., Palacios, A., \& Ayestaran, B. (2007). Maceration enzymes and

635 mannoproteins: A possible strategy to increase colloidal stability and color extraction in red

636 wines. The Journal of Agricultural and Food Chemistry, 55, 4854-4862.

637 Guadalupe, Z., \& Ayestaran, B. (2008). Effect of commercial mannoprotein addition on

638 polysaccharide, polyphenolic, and color composition in red wines. The Journal of

639 Agricultural and Food Chemistry, 56, 9022-9029. 
640 Idris, O.H.M., Williams, P.A., \& Phillips, G.O. (1998). Characterization of gum from Acacia

641 senegal trees of different age and location using multidetection gel permeation

642 chromatography. Food Hydrocolloids, 12, 379-388.

643 International Oenological Codex: COEI-1-GOMARA, 2000.

644 Islam, A., Phillips, G., Sljivo, A., Snowden, M., \& Williams, P. (1997). A review of recent

645 developments on the regulatory, structural and functional aspects of gum Arabic. Food

$646 \quad$ Hydrocolloids, 11, 493-505.

647 Lamport, D.T.A., \& Varnai, P. (2013). Periplasmic arabinogalactan glycoproteins act as a

648 calcium capacitor that regulates plant growth and development. New Phytologist, 197, 58-64.

649 Li, X., Zhang, H., Jin, Q., \& Cai, Z. (2018). Contribution of arabinogalactan protein to the 650 stabilization of single-walled carbon nanotubes in aqueous solution of gum Arabic. Food 651 Hydrocolloids, 78, 55-61.

652 Liang, M., Liu, R., Qi, W., Su, R., Yu, Y., Wang, L., \& He, Z. (2013). Interaction between 653 lysozyme and procyanidin: Multilevel structural nature and effect of carbohydrates. Food 654 Chemistry, 138, 1596-1603.

655 Lopez-Torrez, L., Nigen, M., Williams, P., Doco, T., \& Sanchez, C. (2015). Acacia senegal 656 vs. Acacia seyal gums - Part 1: Composition and structure of hyperbranched plant exudates.

657 Food Hydrocolloids, 51, 41-53.

658 Luck, G., Liao, H., Murray, N.J., Grimmer, H.R., Warminski, E.E., Williamson, M.P., Lilley, 659 T.H., \& Haslam, E. (1994). Polyphenols, astringency and proline-rich proteins.

660 Phytochemistry, 37, 357-371.

661 Mahendran, T., Williams, P.A., Phillips, G.O., Al-Assaf, S., \& Baldwin, T.C. (2008). New 662 insights into the structural characteristics of the arabinogalactan-protein (AGP) fraction of 663 gum Arabic. Journal of Agricultural and Food Chemistry, 56, 9269-9276. 
664 Mateus, N., Carvalho, E., Luis, C., \& de Freitas, V. (2004). Influence of the tannin structure 665 on the disruption effect of carbohydrates on protein-tannin aggregates. Analytica Chimica 666 Acta, 513, 135-140.

667 Mejia-Tamayo, V., Nigen, M., Apolinar-Valiente, R., Doco, T., Williams, P., Renard, D., \& 668 Sanchez, C. (2018). Flexibility and hydration of amphiphilic hyperbranched arabinogalactan669 protein from plant exudate: a volumetric perspective. Colloids and Interface, 2, 1-24.

670 Mhinzi, G.S. (2003). Intra-species variation of the properties of gum exudates from Acacia 671 senegal var. senegal and Acacia seyal var. fistula from Tanzania. Bulletin of the Chemical 672 Society of Ethiopia, 17, 67-74.

673 Osman, M.E., Menzies, A.R., Williams, P.A., Phillips, G.O., \& Baldwin, T.C. (1993). The 674 molecular characterization of the polysaccharide gum from Acacia senegal. Carbohydrate 675 Research, 246, 303-318.

676 Pérez $\square$ Lamela, C., García $\square$ Falcón, M.S., Simal $\square$ Gándara, J., \& Orriols $\square$ Fernández, 677 I. (2007). Influence of grape variety, wine system and enological treatments on the colour 678 stability of young red wines. Food Chemistry, 101, 601-606.

679 Poncet-Legrand, C., Doco, T., Williams, P., \& Vernhet, A. (2007). Inhibition of grape seed 680 tannin aggregation by wine mannoproteins: effect of polysaccharide molecular weight.

681 American Journal of Enology and Viticulture, 58, 87-91.

682 Randall, R.C., Phillips, G.O., \& Williams, P.A. (1988). The role of the proteinaceous 683 component on the emulsifying properties of gum arabic. Food Hydrocolloids, 2, 131-140.

684 Randall, R.C., Phillips, G.O., \& Williams, P.A. (1989). Fractionation and characterization of 685 gum from Acacia senegal. Food Hydrocolloids, 3, 65-75.

686 Ray, A.K., Bird, P.B., Iacobucci, A.I., \& Clark, B.C. (1995). Functionality of gum Arabic. 687 Fractionation, characterization and evaluation of gum fractions in citrus oil emulsions and 688 model beverages. Food Hydrocolloids, 9, 123-131. 
Renard, D., Lavenant-Gourgeon, L., Ralet, M.C., \& Sanchez C. (2006). Acacia senegal gum:

690 continuum of molecular species differing by their protein to sugar ratio, molecular weight,

691 and charges. Biomacromolecules, 7, 2637-2649.

692 Renard, D., Garnier, C., Lapp, A., Schmitt, C., \& Sanchez, C. (2012). Structure of

693 arabinogalactan-protein from Acacia gum: From porous ellipsoids to supramolecular

694 architectures. Carbohydrate Polymers, 90, 322-332.

695 Renard, D., Garnier, C., Lapp, A., Schmitt, C., \& Sanchez C. (2013). Corrigendum to

696 "Structure of arabinogalactan-protein from Acacia gum: From porous ellipsoids to

697 supramolecular architectures" [Carbohydrate Polymers 90 (2012) 322-332]. Carbohydrate

698 Polymers, 97, 864-867.

699 Renard, D., Lavenant-Gourgeon, L., Lapp, A., Nigen, M., \& Sanchez, C. (2014). Enzymatic

700 hydrolysis studies of arabinogalactan-protein structure from Acacia gum: The self-similarity

701 hypothesis of assembly from a common building block. Carbohydrate Polymers, 112, 648-

702661.

703 Ribéreau-Gayon, P., Glories, Y., Maujean, A., \& Dubourbieu, D. (2006). Handbook of

704 Enology. Vol. 2. The Chemistry of Wine Stabilization and Treatments, $2^{\text {nd }}$ ed.; Wiley:

705 Chichester, UK.

706 Riou, V., Vernhet, A., Doco, T., \& Moutounet, M. (2002). Aggregation of grape seed tannins

707 in model wine - effect of wine polysaccharides. Food Hydrocolloids, 16, 17-23.

708 Sanchez, C., Schmitt, C., Kolodziejczyk, E., Lapp, A., Gaillard, C., \& Renard, D. (2008). The

709 Acacia gum arabinogalactan fraction is a thin oblate ellipsoid: A new model based on small-

710 angle neuron scattering and ab initio calculation. Biophysical Journal, 94, 629-639.

711 Schmitt, C., Sanchez, C., Thomas, F., \& Hardy, J. (1999). Complex coacervation between $\beta$ -

712 lactoglobulin and acacia gum in aqueous medium. Food Hydrocolloids, 13, 483-496. 
713 Snowden, M.L., Phillips, G.O., \& Williams, P.A. (1987). Functional characteristics of gum

714 arabic. Food Hydrocolloids, 1, 291-300.

715 Soares, S.I., Gonçalves, R.M., Fernandes, I., Mateus, N., \& de Freitas, V. (2009). Mechanistic

716 approach by which polysaccharides inhibit $\alpha$-amylase/procyanidin aggregation. Journal of

717 Agricultural and Food Chemistry, 57, 4352-4358.

718 Soares, S., Mateus, N., \& de Freitas, V. (2012). Carbohydrates inhibit salivary proteins

719 precipitation by condensed tannins. Journal of Agricultural and Food Chemistry, 60, 3966-

7203972.

721 Teissedre, P.L. (2012). Arabic Gum in Oenology. In: Kennedy J.F, Phillips G.O., Williams 722 P.A. (eds) Arabic gum. RSC Publishing, Cambridge.

723 Waters, E.J., Pellerin, P., \& Brillouet, J-M. (1994). A wine arabinogalactan-protein that 724 reduces heat-induced wine protein haze. Bioscience Biotechnology and Biochemistry, 58, 4372548.

726 Waters, E.J., Pellerin, P., \& Brillouet, J-M. (1994a). A Saccharomyces mannoprotein that 727 protects wine from protein haze. Carbohydrate polymers, 23, 185-191.

728 Williams, P.A., \& Phillips, G.O. (2000). Gum Arabic. In G.O. Phillips, \& P.A. Williams 729 (Eds.), Handbook of hydrocolloids, Boca Raton: CRC Press. 


\section{ACCEPTED MANUSCRIPT}

731 Figure 1. Transmittance changes of hydro-alcoholic - mineral solutions without (A) and with

7320.09 (B) and 0.14 g. $\mathrm{L}^{-1}$ (C) of A. senegal gum. The transmittance was registered at $25^{\circ} \mathrm{C}$

733 during $24 \mathrm{~h}$. Pictures of the solutions before and after $24 \mathrm{~h}$ of kinetic are presented on the right.
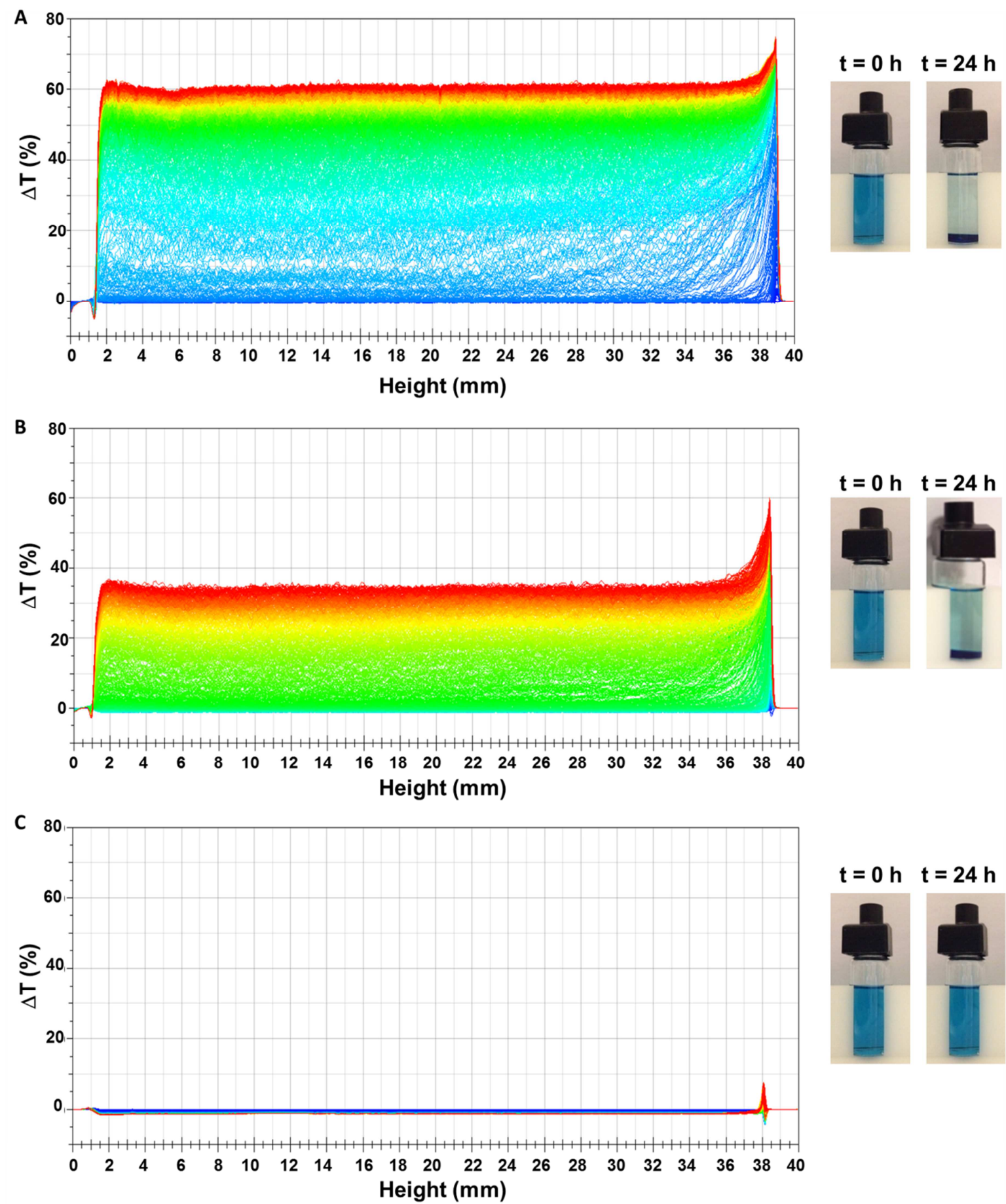
737 Figure 2. (A) Colloid stability kinetics of hydro-alcoholic - mineral solutions containing

738 various A. senegal gum concentrations: $0(\bullet), 0.05(\bullet), 0.08(\bullet), 0.09(\bullet), 0.10(\bullet), 0.11(\bullet)$

739 and $0.14(\bullet)$ g.L $\mathrm{L}^{-1}$. (B) Colloidal stability curve of hydro-alcoholic - mineral solution in

740 presence of A. senegal gum after $24 \mathrm{~h}$ of kinetic. The experiments were performed at $25^{\circ} \mathrm{C}$.

741 The line (figure 2B) is shown to guide the eyes. The experiments were triplicated.

742
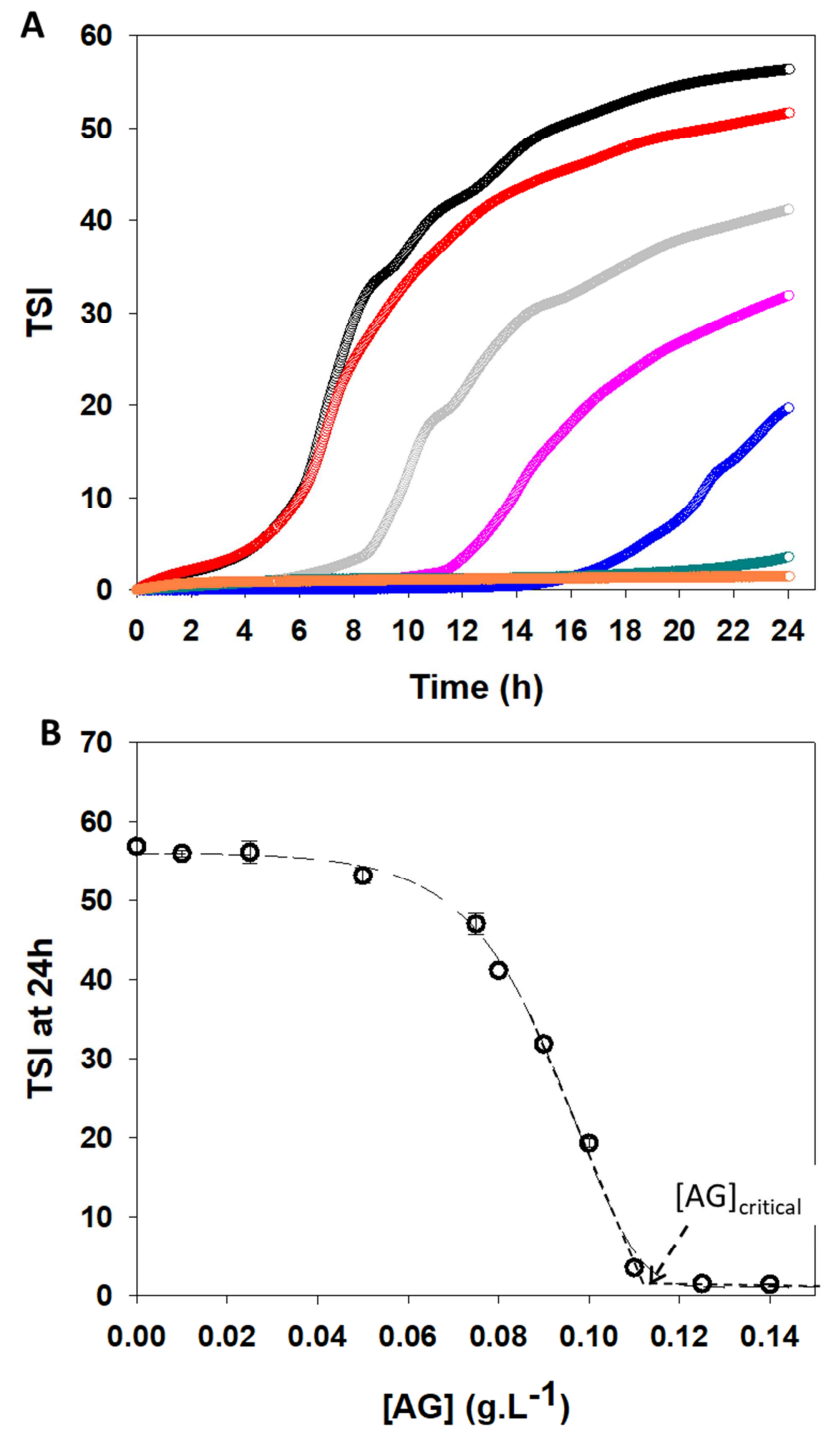

744 


\section{ACCEPTED MANUSCRIPT}

747 Figure 3. (A) Colloidal stability curves of hydro-alcoholic - mineral solutions in presence of

748 A. senegal gum (AG) at pH 3.1 (०), 3.5 (०) and 4.0 (०) after 24h of kinetic. (B) Relationship

749 between the electrophoretic mobility of A. senegal gum (AG) and its critical concentration in

750 hydro-alcoholic - mineral solutions. The lines (figure 3A) are shown to guide the eyes. The

751 experiments were triplicated.
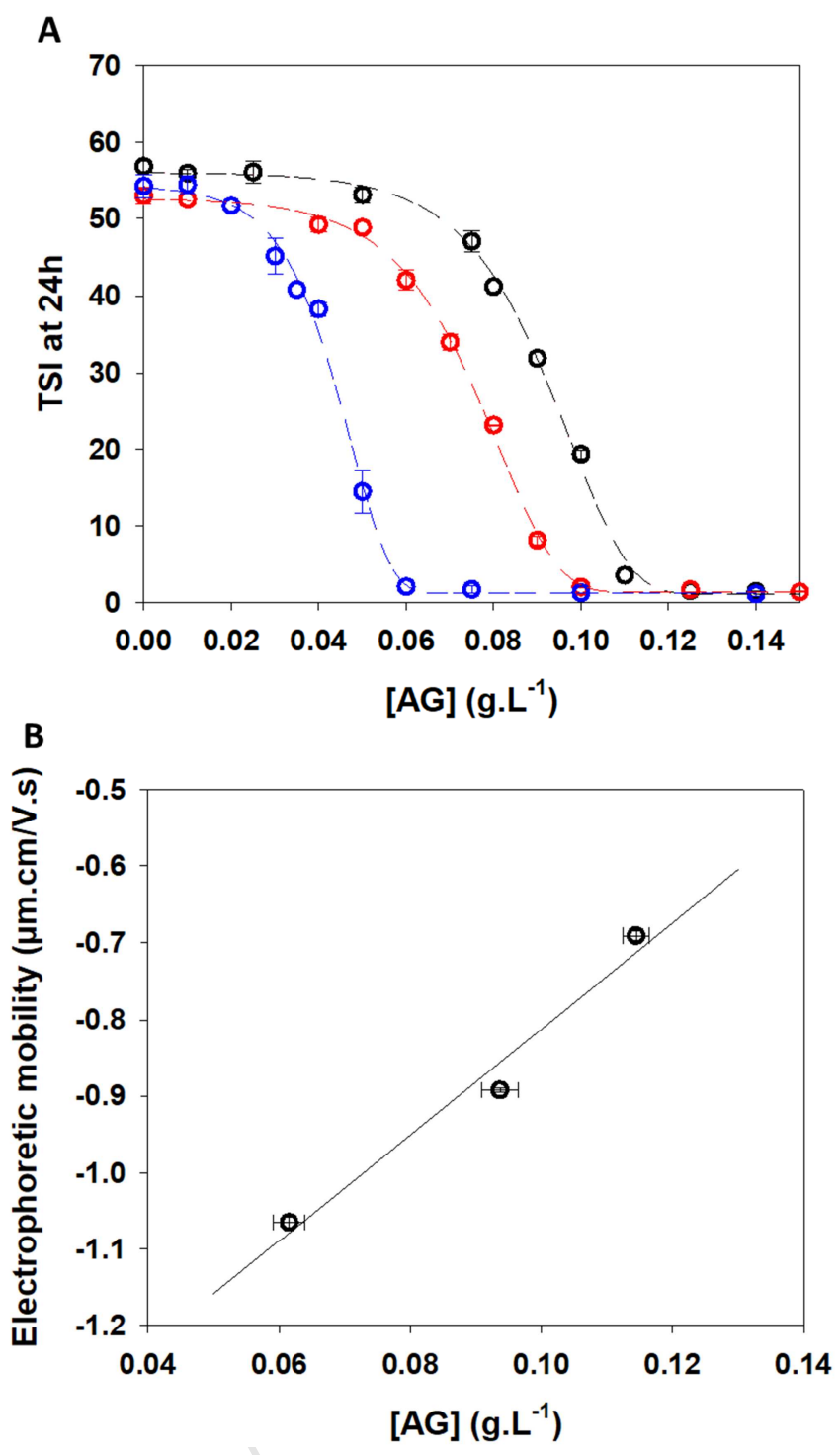

753

754

755 
756 Figure 4. Relationship between the concentration of $\mathrm{Ca}^{2+}$ in the hydro-alcoholic - mineral

757 solution and the critical stabilizing concentration in A. senegal gum ([AG] $]_{\text {crit }}$ ). The 758 experiments were triplicated.

759

760

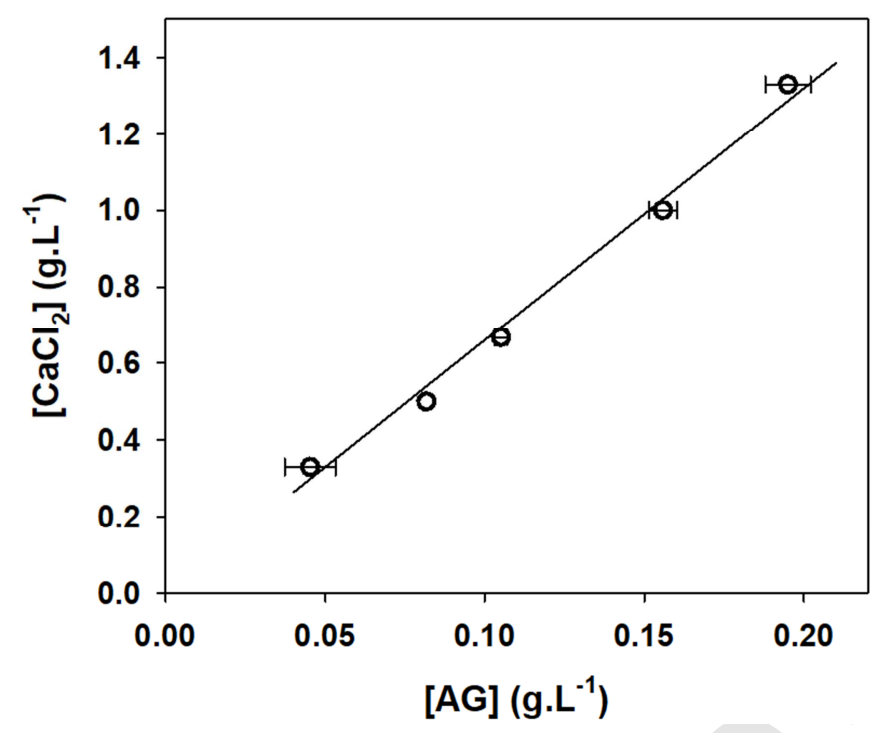

762

763

764

765

766

767

768

769

770

771

772

773 
774 Figure 5. Colloidal stability curves of hydro-alcoholic - mineral solution in presence of A.

775 senegal gum (०), HIC-F1 (०), HIC-F2 (०) and HIC-F3 (०) fractions after 24h of kinetic. The 776 experiments were performed at $25^{\circ} \mathrm{C}$. The lines are shown to guide the eyes. The inset figure 777 is a zoom of the left part. The experiments were triplicated.

778

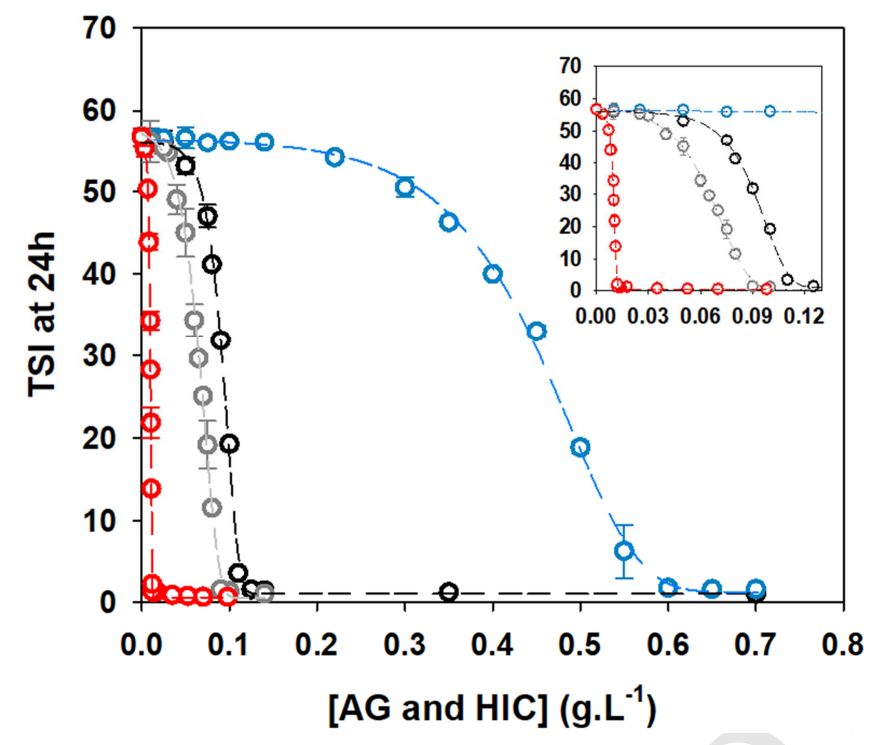

780

781 
782 Figure 6. Molar mass distribution (thick line) and normalized refractive index signal (thin

783 line) of HIC-F1 (A) and A. senegal gum (B) before (black) and after (red) pronase treatment.

784 Colloidal stability curves of hydro-alcoholic - mineral solution in presence of HIC-F1 (C) and

785 A. senegal gum (D) before (०) and after ( $\bullet$ ) pronase treatment after $24 \mathrm{~h}$ of kinetic. The lines

786 (figures 6C and 6D) are shown to guide the eyes. The colloidal stability experiments were

787 triplicated.

788

789
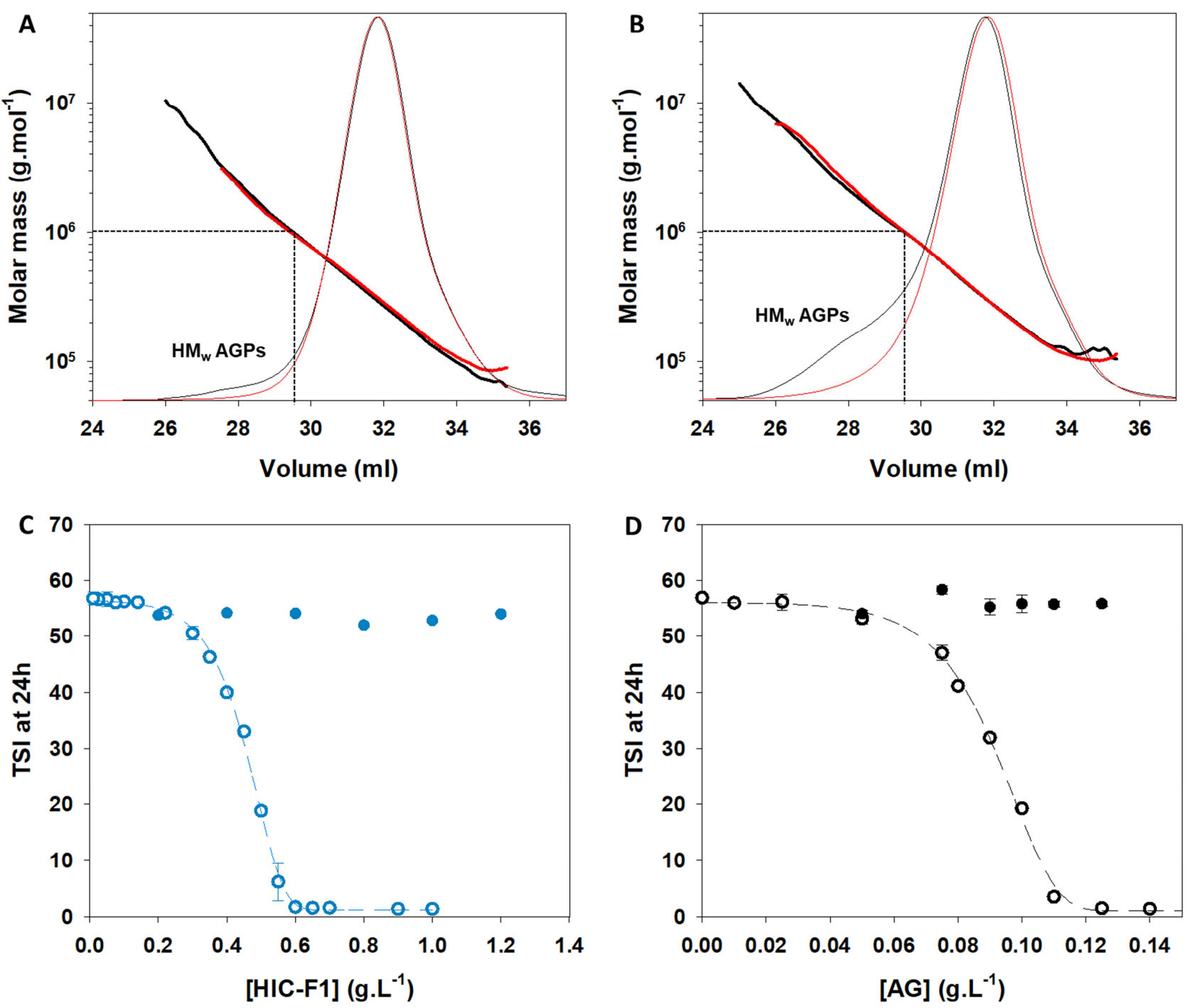


\section{ACCEPTED MANUSCRIPT}

792 Figure 7. (A) Colloid stability kinetic of hydro-alcoholic - grape marc solutions according to

793 A. senegal gum (AG) concentration at $10^{\circ} \mathrm{C}$. The concentrations of A. senegal gum were 0

794 $(\bullet), 0.01(\bullet), 0.025(\bullet), 0.05(\bullet), 0.1(\bullet)$ and $0.5(\bullet)$ g.L ${ }^{-1}$. The colloidal stability kinetic of

795 the hydro-alcoholic - grape marc solution at $25^{\circ} \mathrm{C}$ without A. senegal gum is shown as a

796 control (•) (B) Colloidal stability curves of hydro-alcoholic - grape marc solution in presence

797 of A. senegal gum (०), HIC-F1 (०), HIC-F2 (०) and HIC-F3 (०) fractions after 48h of kinetic

798 at $10^{\circ} \mathrm{C}$. (C) Colloidal stability curves of a young red wine in presence of A. senegal gum (०),

799 HIC-F2 (०) and HIC-F3 (०) fractions after $48 \mathrm{~h}$ of kinetic at $10^{\circ} \mathrm{C}$. The lines (figures $7 \mathrm{~B}$ and

800 7C) are shown to guide the eyes. The inset figure is a zoom of the left part. The experiments

801 were triplicated.

802

803 

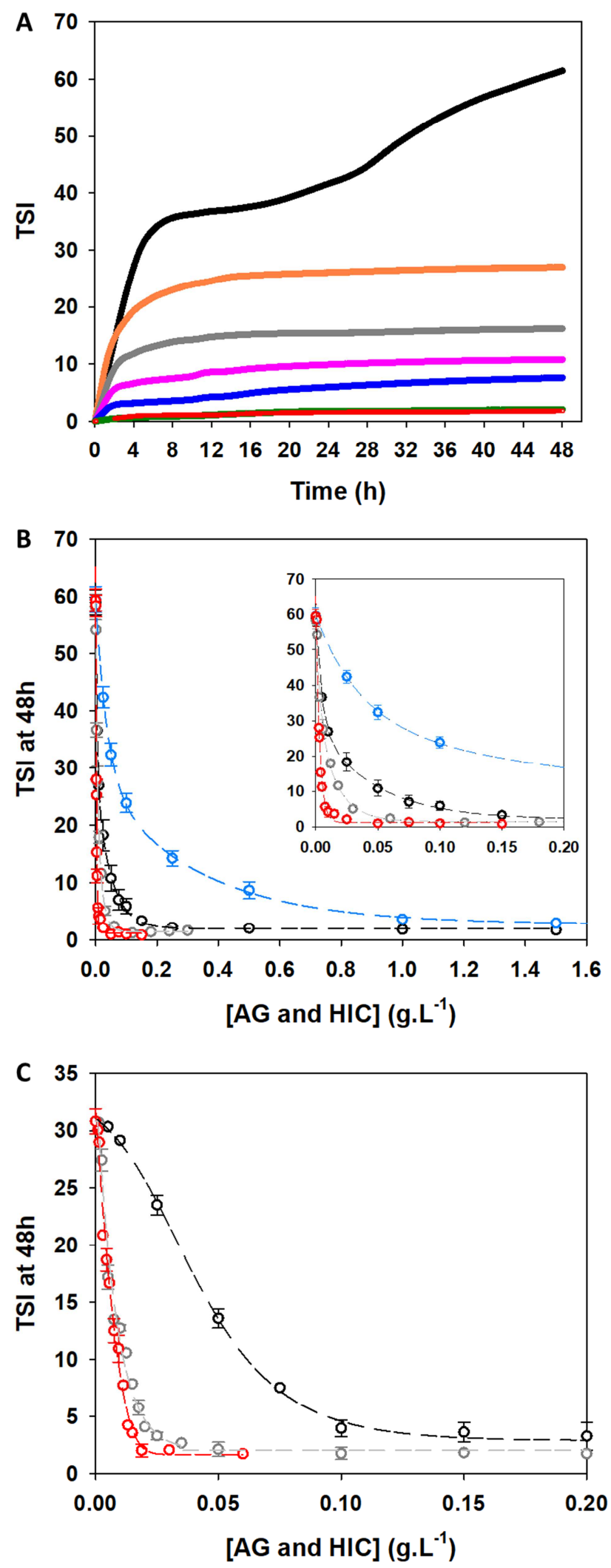

804

[AG and HIC] (g. $\left.\mathrm{L}^{-1}\right)$

805 
806 Figure 8. Relationship between the critical concentrations of A. senegal gum (AG) and its

807 HIC-fractions determined in hydro-alcoholic - mineral solution and those determined in

808 hydro-alcoholic grape marc solution (A) and young red wine (B). The experiments were 809 triplicated.

810
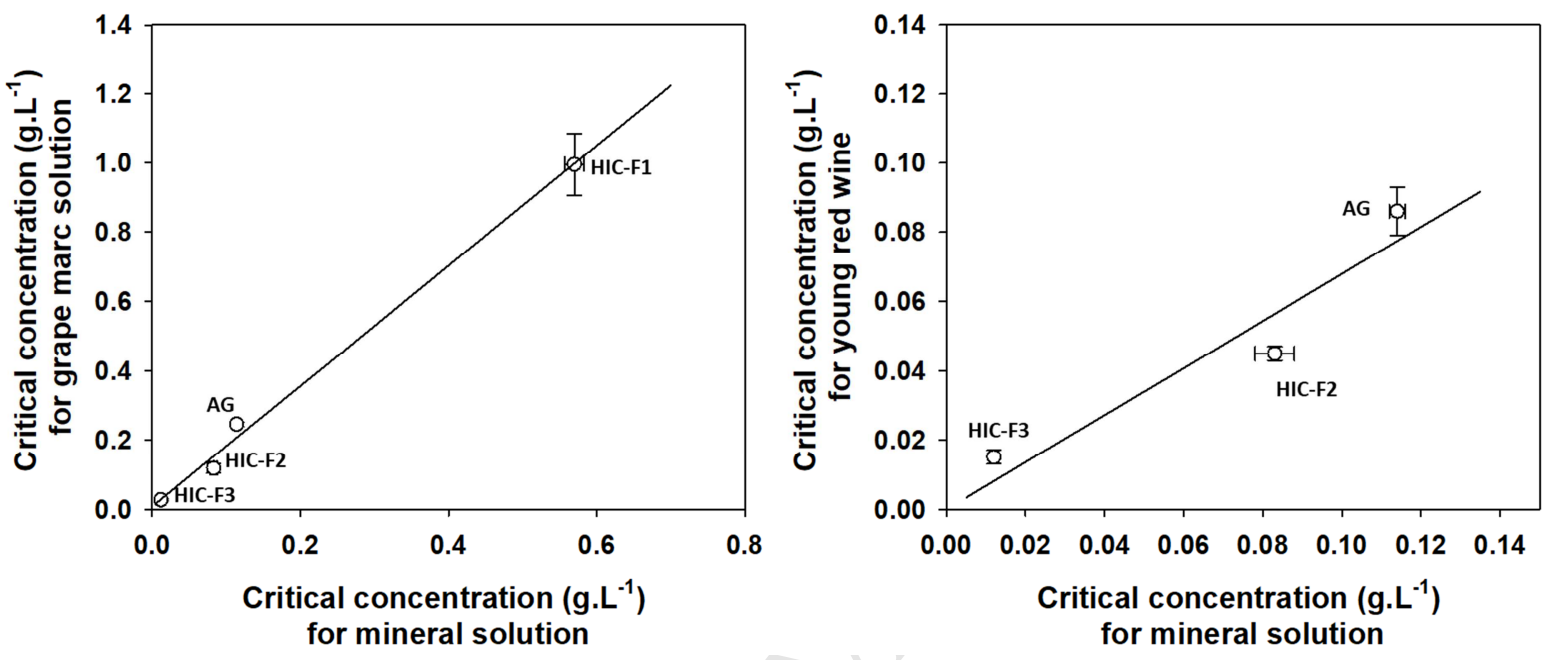

812

813

814

815

816

817

818

819

820

821

822

823

824 
826 Supplementary table 1. Biochemical and structural properties of Acacia senegal gum (AG),

827 and its HIC fractions.

828

\begin{tabular}{|c|c|c|c|c|}
\hline & $\overline{A G}$ & HIC-F1 & HIC-F2 & HIC-F3 \\
\hline Total dry matter $\left(\mathrm{mg} \cdot \mathrm{g}^{-1}\right)$ & 893.4 & 921.6 & 926.2 & 921.9 \\
\hline Sugars (mg.g $\left.\mathrm{g}^{-1}\right)$ & 944.4 & 961.3 & 918.3 & 813.0 \\
\hline Galactose & 363.6 & 374.9 & 315.9 & 270.7 \\
\hline Arabinose & 281.4 & 257.6 & 326.9 & 311.4 \\
\hline Rhamnose & 120.9 & 120.2 & 125.8 & 113.0 \\
\hline Glucuronic acid & 168.1 & 195.1 & 143.3 & 111.4 \\
\hline 4-O-Me-Glucuronic acid & 9.4 & 13.5 & 5.5 & 5.7 \\
\hline Proteins $\left(m g \cdot g^{-1}\right)$ & 21.5 & 4.9 & 63.1 & 137.7 \\
\hline $\operatorname{Ash}\left(\mathrm{mg} \cdot \mathrm{g}^{-1}\right)$ & 34.1 & 30.5 & 19.3 & 49.3 \\
\hline $\mathrm{M}_{\mathrm{w}}\left(\mathrm{g} \cdot \mathrm{mol}^{-1}\right)$ & $6.8 \times 10^{5}$ & $3.5 \times 10^{5}$ & $1.5 \times 10^{6}$ & $1.6 \times 10^{6}$ \\
\hline High $\mathrm{M}_{\mathrm{w}}$ content $(\%)^{\mathrm{a}}$ & 14 & 3 & 73 & 56 \\
\hline
\end{tabular}

829

$830{ }^{\mathrm{a}}$ The high $\mathrm{M}_{\mathrm{w}}$ corresponded to macromolecules with a $\mathrm{M}_{\mathrm{w}}$ upper than $10^{6} \mathrm{~g} \cdot \mathrm{mol}^{-1}$.

831

832 


\section{Highlights.}

- AGPs from Acacia senegal gum prevent the coloring matter precipitation

- The more AGPs are rich in proteins, the more their stabilizing efficiency are

- Stabilizing properties of AGPs are correlated in "synthetic" solutions and red wine

- In "synthetic" mineral solution, AGPs avoid the precipitation by $\mathrm{Ca}^{2+}$ binding 